\title{
Seasonal variation and spatial distribution of carbonaceous aerosols in Taiwan
}

\author{
C. C.-K. Chou ${ }^{1}$, C. T. Lee $^{2}$, M. T. Cheng ${ }^{3}$, C. S. Yuan $^{4}$, S. J. Chen ${ }^{5}$, Y. L. Wu ${ }^{6}$, W. C. Hsu ${ }^{7}$, S. C. Lung ${ }^{1}$, S. C. Hsu ${ }^{1}$, \\ C. Y. Lin $^{1}$, and S. C. Liu ${ }^{1}$ \\ ${ }^{1}$ Research Center for Environmental Changes, Academia Sinica, Taipei, Taiwan \\ ${ }^{2}$ Institute of Environmental Engineering, National Central University, Chungli, Taiwan \\ ${ }^{3}$ Department of Environmental Engineering, National Chung Hsing University, Taichung, Taiwan \\ ${ }^{4}$ Institute of Environmental Engineering, National Sun Yat-Sen University, Kaohsiung, Taiwan \\ ${ }^{5}$ Department of Environmental Science and Engineering, National Pingtung University of Science and Technology, \\ Pingtung, Taiwan \\ ${ }^{6}$ Department of Environmental Engineering, National Cheng Kung University, Tainan, Taiwan \\ ${ }^{7}$ Department of Environmental Resources Management, Dahan Institute of Technology, Hualien, Taiwan
}

Received: 2 March 2010 - Published in Atmos. Chem. Phys. Discuss.: 16 March 2010

Revised: 27 August 2010 - Accepted: 16 September 2010 - Published: 11 October 2010

\begin{abstract}
To investigate the physico-chemical properties of aerosols in Taiwan, an observation network was initiated in 2003. In this work, the measurements of the mass concentration and carbonaceous composition of $\mathrm{PM}_{10}$ and $\mathrm{PM}_{2.5}$ are presented. Analysis on the data collected in the first 5-years, from 2003 to 2007, showed that there was a very strong contrast in the aerosol concentration and composition between the rural and the urban/suburban stations. The five-year means of $\mathrm{EC}$ at the respective stations ranged from $0.9 \pm 0.04$ to $4.2 \pm 0.1 \mu \mathrm{gC} \mathrm{m}{ }^{-3}$. In rural areas, $\mathrm{EC}$ accounted for 2-3\% of $\mathrm{PM}_{10}$ and 3-5\% of $\mathrm{PM}_{2.5}$ mass loadings, comparing to $4-6 \%$ of $\mathrm{PM}_{10}$ and $4-8 \%$ of $\mathrm{PM}_{2.5}$ in the urban areas. It was found that the spatial distribution of $\mathrm{EC}$ was consistent with $\mathrm{CO}$ and $\mathrm{NO}_{\mathrm{x}}$ across the network stations, suggesting that the levels of EC over Taiwan were dominated by local sources. The measured OC was split into POC and SOC counterparts following the EC tracer method. Five-year means of POC ranged from $1.8 \pm 0.1$ to $9.7 \pm 0.2 \mu \mathrm{gC} \mathrm{m}^{-3}$ among the stations. It was estimated that the POM contributed $5-17 \%$ of $\mathrm{PM}_{10}$ and $7-18 \%$ of $\mathrm{PM}_{2.5}$ in Taiwan. On the other hand, the five-year means of SOC ranged from $1.5 \pm 0.1$ to $3.8 \pm 0.3 \mu \mathrm{gC} \mathrm{m}^{-3}$. The mass fractions of SOM were estimated to be $9-19 \%$ in $\mathrm{PM}_{10}$ and 14 $22 \%$ in $\mathrm{PM}_{2.5}$. The results showed that the SOC did not exhibit significant urban-rural contrast as did the POC and EC.
\end{abstract}

Correspondence to: C. C.-K. Chou

(ckchou@ rcec.sinica.edu.tw)
A significant cross-station correlation between SOC and total oxidant was observed, which means the spatial distribution of SOC in Taiwan was dominated by the oxidant mixing ratio. Besides, correlation was also found between SOC and particulate nitrate, implying that the precursors of SOA were mainly from local anthropogenic sources. In addition to the spatial distribution, the carbonaceous aerosols also exhibited distinct seasonality. In northern Taiwan, the concentrations of all the three carbonaceous components (EC, POC, and SOC) reached their respective minima in the fall season. POC and EC increased drastically in winter and peaked in spring, whereas the SOC was characterized by a bimodal pattern with the maximal concentration in winter and a second mode in summertime. In southern Taiwan, minimal levels of POC and EC occurred consistently in summer and the maxima were observed in winter, whereas the SOC peaked in summer and declined in wintertime. The discrepancies in the seasonality of carbonaceous aerosols between northern and southern Taiwan were most likely caused by the seasonal meteorological settings that dominated the dispersion of air pollutants. Moreover, it was inferred that the Asian pollution outbreaks could have shifted the seasonal maxima of air pollutants from winter to spring in the northern Taiwan, and that the increases in biogenic SOA precursors and the enhancement in SOA yield were responsible for the elevated SOC concentrations in summer.

Published by Copernicus Publications on behalf of the European Geosciences Union. 


\section{Introduction}

It is recognized that atmospheric aerosols have significant influences on the radiative budget of the earth-atmosphere system and, consequently, could have substantial impacts upon the climate (Kanakidou et al., 2005; IPCC, 2007 and references therein). Besides, a number of studies indicated consistently that exposures to airborne particulate matters could result in adverse effects on public health, particularly on the respiratory and cardiovascular systems (e.g., Davidson et al., 2005; Pope and Dockery, 2006; Lippmann, 2007). Despite the well established qualitative understanding, to date, a precise quantitative assessment of the aerosol effects is hard to achieve because the concentration and composition, and hence the physico-chemical properties, of atmospheric aerosols are highly variable over different spatial and temporal scales.

Carbonaceous species are among the major constituents of atmospheric aerosols. However, the evaluation of the environmental and health impacts of the carbonaceous aerosols is still subject to significant uncertainties. In addition to the spatial and temporal variations, the major difficulties are arisen also from the complex nature of the composition. Carbonaceous aerosols are composed of a vast number of compounds that have not been totally resolved even using the most state-of-art instrument (Hallquist et al., 2009 and references therein). Consequently, most of the investigations reported the measurements in terms of "organic carbon (OC)" and "elemental carbon (EC)", which are not adequate to infer the molecular constitution of the carbonaceous species in the aerosols and hence prevent us from predicting and depicting their properties and behavior according to the classic chemistry and physics. The difficulties are also due to the complexity of the formation mechanisms and the emission profiles. The EC in aerosols is produced by incomplete combustion processes, which include anthropogenic sources such as fossil fuel combustion and natural sources like forest fires (McMurry et al., 2004; Hu et al., 2009). The sources of OC are even more complicated, which could be emitted directly from specific sources into the atmosphere or produced from the reactions of precursor hydrocarbons. Accordingly, the organic aerosols are usually divided into "primary organic aerosols (POA)" and "secondary organic aerosols (SOA)". In urban areas, the POA are believed to be mostly from the exhaust of vehicles, whereas biomass burning was suggested as the predominant POA source on global scale (Hallquist et al., 2009). In contrast to the relatively clear picture of POA sources, the production of SOA is likely one of the most complicated issues in atmospheric chemistry as the reaction mechanisms and the precursors have not been fully understood or discovered (Donahue et al., 2009).

Quantification of the concentration of SOC and/or SOA has been a challenge for years. The core issue is that the mass of SOA can not be measured directly. In the last two decades, several alternative methods were developed to esti- mate the amount of SOC/SOA based on the measurements of the gaseous and/or particulate tracers (Turpin and Huntzicker, 1995; Schauer, 1996, 2002; Takegawa et al., 2006; Szidat et al., 2006; Gelencser et al., 2007; Docherty et al., 2008; Blanchard et al., 2008). These investigations consistently suggested that SOA constituted a considerable portion of the particulate matters in the atmosphere. Meanwhile, smog chamber studies on the formation of SOA from specific precursors have significantly improved our understandings of the physical and chemical processes responsible for SOA production (Odum et al., 1996; Forstner et al., 1997; Klotz et al., 1998; Jang and Kamens, 1999; Cocker et al., 2001; Inuma et al., 2004; Edney et al., 2005; Li et al., 2007; Sato et al., 2007). The results of these laboratory experiments provide a framework to describe SOA production mechanisms and allow the theoretical calculation of the yields of particular SOA compounds (Jenkin, 2004; Russell and Allen, 2005; Ng et al., 2006; Presto and Donahue, 2006; Pathak et al., 2007; Saathoff et al., 2009). However, most of the field studies indicated that the contribution of SOA to the mass loading of total aerosols were significantly larger than as expected (e.g., Johnson et al., 2006; Simpson et al., 2007). The discrepancies between simulated and observed levels of SOA could be attributed to problems in the parameterization of SOA formation mechanisms, ignoring some precursors, and/or missing some sources. Besides, on the other hand, it should be noted that the evaluation of SOA models could also suffer from the uncertainties in the indirectly "measured" SOA concentrations.

Taiwan is a densely populated and industrialized area and, consequently, there are substantial emissions of anthropogenic air pollutants over the island. Furthermore, Taiwan is located under the lee side of the East-Asian winter monsoons; the particulate pollutants originating in the Asian continent, in particular the eastern China, could be transported to Taiwan on the northeasterlies of the monsoons, which could in turn increase the concentration and influence the composition of the ambient aerosols. Although the impacts of particulate matters are recognized, there was not a representative long-term dataset of the aerosol composition in Taiwan until recent years (Chang et al., 2010). The Taiwan Aerosol Observation Network was organized to study the formation and transport mechanisms of the atmospheric aerosols. In this work, the measurements of OC and EC from 2003 to 2007 are presented. The EC tracer method was applied to divide the OC into primary and secondary counterparts. Seasonal variation and spatial distribution of the carbonaceous components in $\mathrm{PM}_{10}$ and $\mathrm{PM}_{2.5}$ were analyzed and discussed in details.

\section{Experimental methods}

To investigate the physical and chemical properties of aerosols in Taiwan, a sampling network consisting of 7 stations was initiated in 2003. Figure 1 illustrates the 
geographical locations of the respective stations. In summary, there are two rural stations and five urban/suburban stations. The Cape Fuguei is located at the northern tip of Taiwan and Penghu is on a small isle in the Taiwan Strait, which is ca. $65 \mathrm{~km}$ off the western coast of Taiwan. The urban/suburban stations Taipei, Taichung, Tainan, and Pingtung line in the western plains where most of the people live and are highly developed and industrialized. Hualien is a small city by the eastern coast of Taiwan and the station is ca. $10 \mathrm{~km}$ north from the downtown.

Since the spring of 2003, regular $\mathrm{PM}_{10} / \mathrm{PM}_{2.5}$ sampling has been conducted at the network stations during the last week of each month. At times some episode-based sampling activities were also arranged. The sampling period of each sample was usually $12 \mathrm{~h}$ : daytime samples were collected from 08:00 to 20:00 (LST = GMT + 08:00), and nighttime sampling was from 20:00 to 08:00 (LST). Sometimes the sampling was conducted on daily base, i.e. from 08:00 to 08:00 of the next day. Thus, in the following data analysis, all the half-day measurements will be paired to assimilate to the daily measurements. Those unpaired data (i.e. without the day/night counterpart) are thereby not included in this study. Moreover, the data did not include any rainy event because the sampling cannot be conducted on rainy days. On rainy days, wet deposition of water soluble OC will be enhanced significantly and the formation of SOC could be suppressed even more than on cloudy days. Thus, the annual and seasonal means of aerosols, and also the OC/EC ratio should have been overestimated to a certain degree.

Mass concentration of $\mathrm{PM}_{10} / \mathrm{PM}_{2.5}$ was determined by gravimetric measurement of the samples collected on PTFE filters. The PTFE filter samples were then used for the analysis of soluble ions, which is not the subject of this study and is presented elsewhere (e.g., Chou et al., 2008). The samples for carbonaceous analysis were collected on quartz fiber filters. Before sampling, all the filters were baked under $900^{\circ} \mathrm{C}$ for $3 \mathrm{~h}$ to remove organic contaminates. Laboratory test showed that the blank level of total carbon of the pre-fired filters is below the detection limit of the analyzer. The mass loadings of organic carbon (OC) and elemental carbon (EC) on the filter samples were analyzed using a DRI2001A carbonaceous aerosol analyzer, following the IMPROVE thermo-optical reflectance (TOR) protocol (Chow et al., 2001). The analyzer was calibrated periodically using KHP standards. Moreover, daily quality check of the instrument was carried out using blank filter and 900 ppm-C KHP spike. The criterion of the recovery of the $900 \mathrm{ppm}-\mathrm{C}$ KHP spike was set as from 0.95 to 1.05 , i.e. allowing an error of $5 \%$. The detection limit of the analyzer was determined as 3 times the standard deviation of the signals of 10 blank filters, which thereby included the uncertainties due to filter effects in addition to that of the instrument itself. Given an effective filter area of $10.68 \mathrm{~cm}^{2}$ and the nominal sampling volume of 10 liter-per-minute, the total carbon detection limit of a $24 \mathrm{~h}$ sample is $0.2 \mu \mathrm{gC} \mathrm{m}^{-3}$.

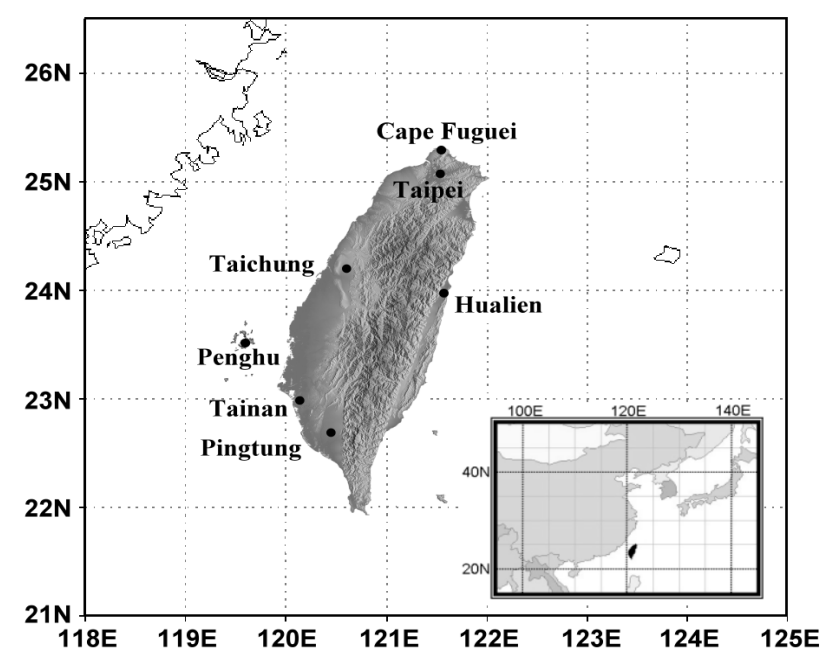

Fig. 1. Geographical locations of the sampling stations of the Taiwan Aerosol Observation Network.

\section{Estimation of secondary organic aerosols}

In this section, the organic carbon is split into primary (POC) and secondary (SOC) counterparts following the EC tracer method. Because this approach has been discussed and applied in a number of papers (e.g., Turpin and Huntzicker, 1995; Russell et al., 2004), only a brief description is given here.

The fundamental assumption of the EC tracer method is that the amount of POC is linearly proportional to $\mathrm{EC}$ in the aerosols:

$\mathrm{POC}=\alpha * \mathrm{EC}+\beta$.

Turpin and Huntzicker (1995) attributed the $\alpha * \mathrm{EC}$ to the POC emitted together with the EC from combustion sources, and suggested the intercept, $\beta$, being the amount of POC generated from non-combustion sources.

In turn, the SOC is determined by subtracting the POC from the total OC:

$\mathrm{SOC}=\mathrm{OC}_{\text {total }}-\mathrm{POC}$.

The major flaw in this approach is that the scaling factor, $\alpha$, is a source-specific parameter. Starting from an emission inventory, one can estimate the amount of POC from each single source if the emission rate of $\mathrm{EC}$ and the $\mathrm{POC} / \mathrm{EC}$ ratio are available. Unfortunately, it is not such a simple way for a filter sample of aerosols. The particulate matters collected on a filter are usually coming from a wide range of sources. Therefore, one cannot apply Eq. (1) directly to determine the POC unless the source apportionment of EC has been resolved and the POC/EC ratios of the respective sources are known (e.g., Gray and Cass, 1986). The other possibility is that the source mix does not change temporally and, consequently, a characteristic $\alpha$ value can be available for a specific area. In practice, the characteristic $\alpha$ (i.e. 
$\mathrm{POC} / \mathrm{EC}$ ratio) of a given area is usually derived from the measurements of OC and EC on days with low photochemical activity (e.g., Russell et al., 2004; Polidori et al., 2006). The underlying assumption of this approach is that the dayto-day variations in the emission profiles of $\mathrm{POC}$ and $\mathrm{EC}$ are negligible, in spite of the pronounced diurnal cycles for the traffics. Obviously, successful application of the EC tracer method depends on the representativeness of the POC/EC ratio.

In this study, given the benefits of a large data set accumulated over 5 years, the distribution of OC/EC of each sampling site can be analyzed statistically. The data with OC/EC ratio less than the 10th percentile, i.e. the left tail of the distribution, were selected and assumed being dominated by primary emissions. Linear regression was in turn applied to these data and the relationship between POC and EC was formulated. Figures 2-3 illustrate the OC/EC distributions and the regression analyses of $\mathrm{PM}_{10}$ and $\mathrm{PM}_{2.5}$ measurements, respectively, for the network stations. The values of $\alpha$ and $\beta$ for each site are summarized in Table 1 . The $\alpha$ values of $\mathrm{PM}_{10}$ ranged from 1.43 to 1.85 in the western Taiwan (including Penghu), whereas an obviously high value of 2.36 turned out for Hualien station. This could be a result of the differences in source profile; Hualien is a small town and has less diesel vehicles than in the highly developed West-Taiwan (Taiwan EPA, 2010). Nevertheless, the values of $\alpha$ observed in this study are comparable with those for many other urban areas, which range from $1.20-1.58$ in Tokyo (Miyazaki et al., 2006), 1.0-3.1 in Beijing (Lin et al., 2009) to $2.7 \pm 0.5$ in Pittsburgh (Cabada et al., 2004). Furthermore, these observations are generally consistent with the most updated emission inventory for Asia where $\mathrm{OC} / \mathrm{BC}=2.24$ in 2006 (Zhang et al., 2009); however, there are significant differences between the respective urban observations and their corresponding national emissions. Note that significant $\beta$ values were found in the central and southern Taiwan, the major agricultural areas of Taiwan, which indicates that the contributions of noncombustion sources to the organic aerosols were substantial in those areas. The significant offset could be also due to the positive artifacts of sampling, i.e. VOC adsorption. In this study, the field blanks showed that the interference of VOCs was around $5-10 \%$ of the total measured OC. The $\alpha$ values of $\mathrm{PM}_{2.5}$ differ slightly from those of $\mathrm{PM}_{10}$, reflecting that the carbonaceous species existed mostly in the fine aerosols. The causes of the negative $\beta$ for Taipei are not clear yet. The negative $\beta$ is significant in terms of statistics; however, which is certainly meaningless in physics. The most plausible cause could be the negative sampling artifacts, i.e. the evaporation loss. However, the loss should be a common issue for all the stations. Besides, the selection of samples for the regression analysis is also a source of uncertainties. For instance, using the lowest $15 \%$ (OC/EC) ratio as the criterion will shift the $\beta$ approaching zero.

Ideally, the values of $\alpha$ and $\beta$ should be derived from measurements of specific season and specific site. How- ever, in practice, such a task is usually subject to the number of samples. Thus, the approach of data analysis depends on the constraints of each study. For instance, Yuan et al. (2006) lumped their data from all the stations together to derive "season-specific" $\mathrm{POC/EC} \mathrm{ratios} \mathrm{because} \mathrm{the} \mathrm{sources}$ of aerosols in Hong-Kong were changed with seasonal meteorological conditions, particularly in summertime. On the contrary, in this study, we assumed that the primary emission profiles of OC and EC were not season-dependent and, in turn, used the year-round dataset of each site to derive "sitespecific" parameters. In this context, the spatial distribution of SOC presented in this paper was more representative than the seasonality, which could have been biased to some extent. To evaluate the uncertainties in the SOC estimates due to applying the season-independent parameters, we have derived season-specific parameters for the cases where the seasonal sample numbers are more than 50 at a specific site. The results are listed in the supplemental Tables S1 and S2. In summary, the differences between the season-specific $\alpha$ values and the corresponding year-round $\alpha$ values are within $50 \%$. The seasonal variations in the $\beta$ values are relatively pronounced, but the absolute values are small. As a result, in those cases, the seasonal means of SOC concentration calculated using season-specific parameters are consistent with that calculated using season-independent parameters; the differences are within 30\%. Moreover, we also applied seasonspecific minimal OC/EC ratios measured at the respective stations to calculate the seasonal SOC concentrations (Castro et al., 1999). The SOC levels calculated using the method described above and the Castro's (OC/EC) min method, respectively, were compared in Tables S1-S2 of the supplemental material of this paper. Obviously, applying season-specific $(\mathrm{OC} / \mathrm{EC})_{\min }$ did not alter the spatial distribution and seasonal pattern of SOC although this method tends to give higher SOC concentrations. Thus, the results of the seasonal variation and spatial distribution of SOC discussed in this paper are warranted, and the bias due to using season-independent parameters should be rather limited in our case.

\section{Contributions of carbonaceous species to the aerosol mass loadings}

Given the regression parameters listed in Table 1, one can estimate the levels of POC and SOC, respectively, in each aerosol sample. Table 2 summarizes the descriptive statistics of the annual means of EC, POC, and SOC for all the network stations from 2003 to 2007. During the five years, there were obvious inter-annual variations in the concentrations of carbonaceous aerosols in Taiwan. However, the data did not show significant inter-annual trends in the mean levels of EC, POC, and SOC at all the stations. Nevertheless, it should be noted that a 5-year dataset could not be enough to infer a long-term trend. 

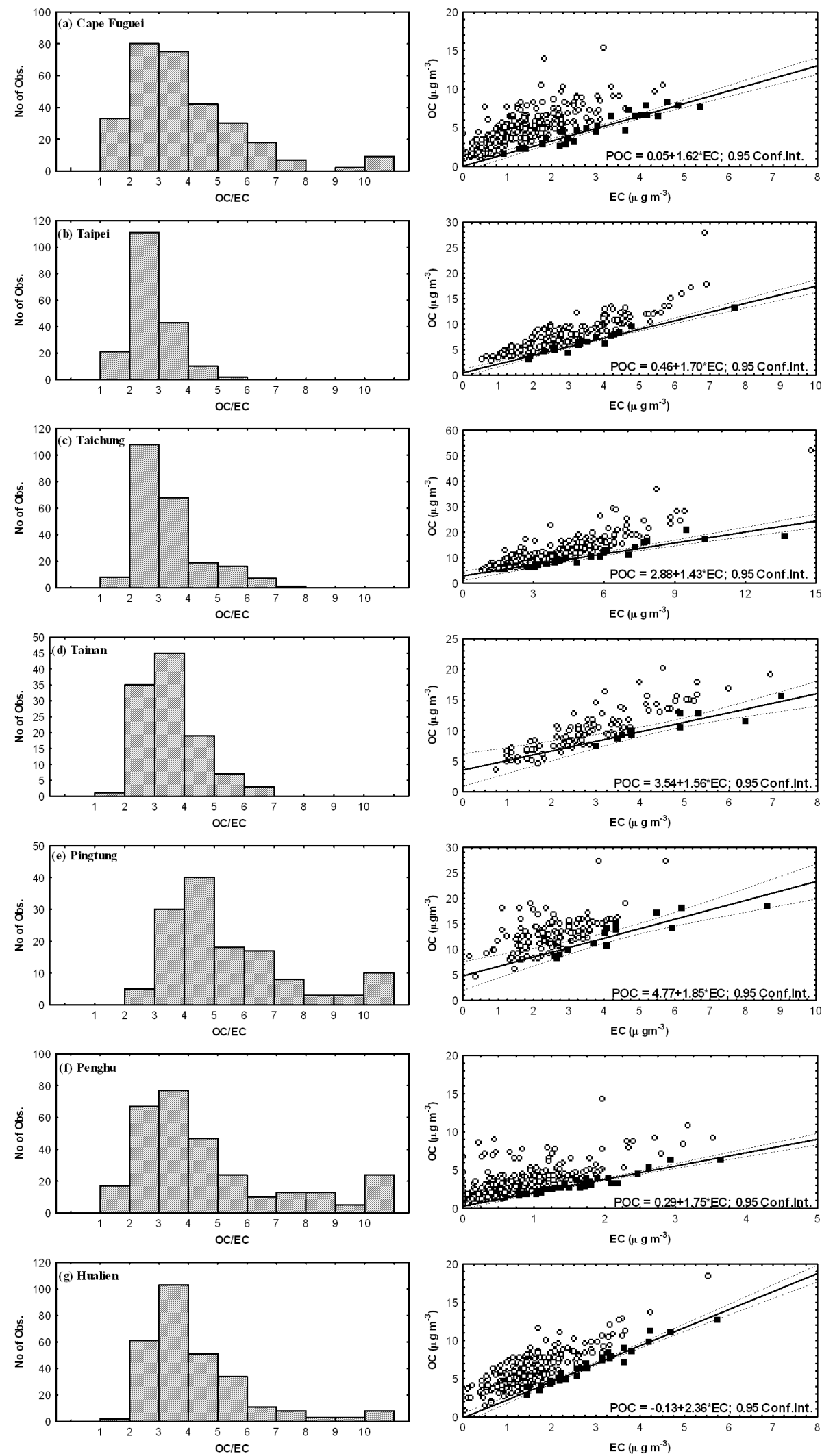

Fig. 2. Histograms of OC/EC ratios and scattering plots of OC vs. EC for $\mathrm{PM}_{10}$ of respective stations. Data with the lowest $10 \%$ OC/EC ratio are shown as solid squares, which were analyzed with linear regression model to derive the site-specific primary OC/EC ratio. 

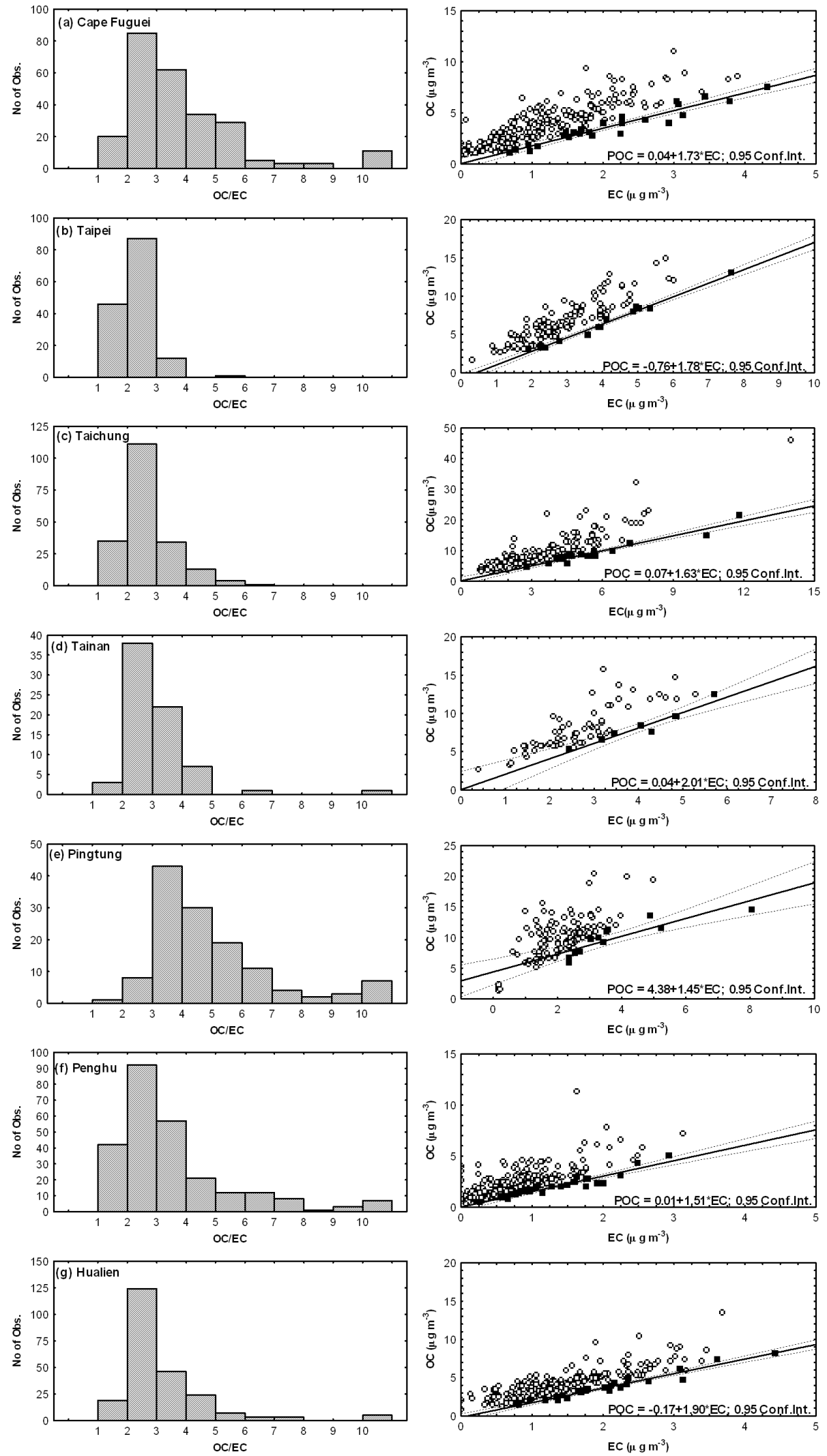

Fig. 3. Same as Fig. 2 but for $\mathrm{PM}_{2.5}$. 
Table 1. Summary of linear regression for the relationship between primary organic carbon and elemental carbon $(\mathrm{POC}=\alpha * \mathrm{EC}+\beta)$.

\begin{tabular}{lrrrr}
\hline & \multicolumn{2}{c}{$\mathrm{PM}_{10}$} & $\beta$ & \multicolumn{2}{c}{$\mathrm{PM}_{2.5}$} & $\beta$ \\
\hline Cape Fuguei & $1.62 \pm 0.10^{*}$ & $0.05 \pm 0.33$ & $1.73 \pm 0.11^{*}$ & $0.04 \pm 0.25$ \\
Taipei & $1.70 \pm 0.09^{*}$ & $0.46 \pm 0.35$ & $1.78 \pm 0.07^{*}$ & $-0.76 \pm 0.29^{*}$ \\
Taichung & $1.43 \pm 0.14^{*}$ & $2.88 \pm 0.88^{*}$ & $1.63 \pm 0.10^{*}$ & $0.07 \pm 0.61$ \\
Tainan & $1.56 \pm 0.25^{*}$ & $3.54 \pm 1.18^{*}$ & $2.01 \pm 0.23^{*}$ & $0.04 \pm 0.97$ \\
Pingtung & $1.85 \pm 0.27^{*}$ & $4.77 \pm 1.29^{*}$ & $1.45 \pm 0.24^{*}$ & $4.38 \pm 0.96^{*}$ \\
Penghu & $1.75 \pm 0.11^{*}$ & $0.29 \pm 0.19$ & $1.51 \pm 0.11^{*}$ & $0.00 \pm 0.17$ \\
Hualien & $2.36 \pm 0.10^{*}$ & $-0.13 \pm 0.31$ & $1.90 \pm 0.10^{*}$ & $-0.17 \pm 0.22$ \\
\hline
\end{tabular}

* Significant at $95 \%$ confidence level.

Among the network stations, Penghu had the lowest levels of the carbonaceous species in aerosols. Five-year means ( \pm 1 standard error) of EC, POC and SOC were $0.9 \pm 0.04$, $1.8 \pm 0.1$, and $1.5 \pm 0.1 \mu \mathrm{gC} \mathrm{m}^{-3}$, respectively, in $\mathrm{PM}_{10}$, with ca. $65 \%$ of OC and ca. $90 \%$ of EC confined in fine aerosols (i.e. $\mathrm{PM}_{2.5}$ ). At the Cape Fuguei, another rural station of the network, the mean levels of EC, POC and SOC were $1.5 \pm 0.1,2.5 \pm 0.1$, and $2.3 \pm 0.1 \mu \mathrm{gC} \mathrm{m}^{-3}$, respectively, in $\mathrm{PM}_{10}$, and were $1.3 \pm 0.1,2.2 \pm 0.1$, and $1.6 \pm 0.1 \mu \mathrm{gC} \mathrm{m}^{-3}$, respectively, in $\mathrm{PM}_{2.5}$. The concentrations of carbonaceous aerosols in the urban/suburban areas were much higher than at the rural sites. In the western Taiwan, the mean EC (in $\mathrm{PM}_{10}$ ) concentrations ranged from $2.7 \pm 0.1$ (Pingtung) to $4.2 \pm 0.1$ (Taichung) $\mu \mathrm{gC} \mathrm{m}^{-3}$; POC (in $\mathrm{PM}_{10}$ ) ranged from $5.6 \pm 0.2$ (Taipei) to $9.7 \pm 0.2$ (Pingtung) $\mu \mathrm{gC} \mathrm{m}^{-3}$; SOC (in $\mathrm{PM}_{10}$ ) ranged from $2.0 \pm 0.2$ (Tainan) to $3.8 \pm 0.3$ (Taichung) $\mu \mathrm{gC} \mathrm{m}{ }^{-3}$. The urban-rural contrast was even more pronounced in $\mathrm{PM}_{2.5}$. The aerosol concentration in the eastern Taiwan was significantly lower than in the western plains, agreeing with the reduced traffic and industrial emissions. However, it is remarkable that the SOC concentration in Hualien was comparable with those in the western Taiwan. This inconsistency between the primary and secondary components of the carbonaceous aerosols suggests that there could be substantial emissions of biogenic precursors for the production of secondary organic aerosols in the eastern Taiwan. Besides, transport of photochemically aged air mass containing elevated levels of SOC could also result in the inconsistency. Unfortunately, the EC-tracer method cannot distinguish the sources of SOC, and further studies with other tracers were arisen here. The spatial distribution of SOC will be discussed in more details later on.

Figures 4 and 5 illustrate the 5-year mean mass concentrations and pie shares of EC, primary organic matters (POM), and secondary organic matters (SOM) in $\mathrm{PM}_{10}$ and $\mathrm{PM}_{2.5}$, respectively, over Taiwan. Despite the complicated composition of organic aerosols, it is generally assumed that the mass ratio of organic aerosols to the associated OC could range from 1.2 to 1.4 in urban areas. However, some more recent studies suggested that the secondary organic aerosols

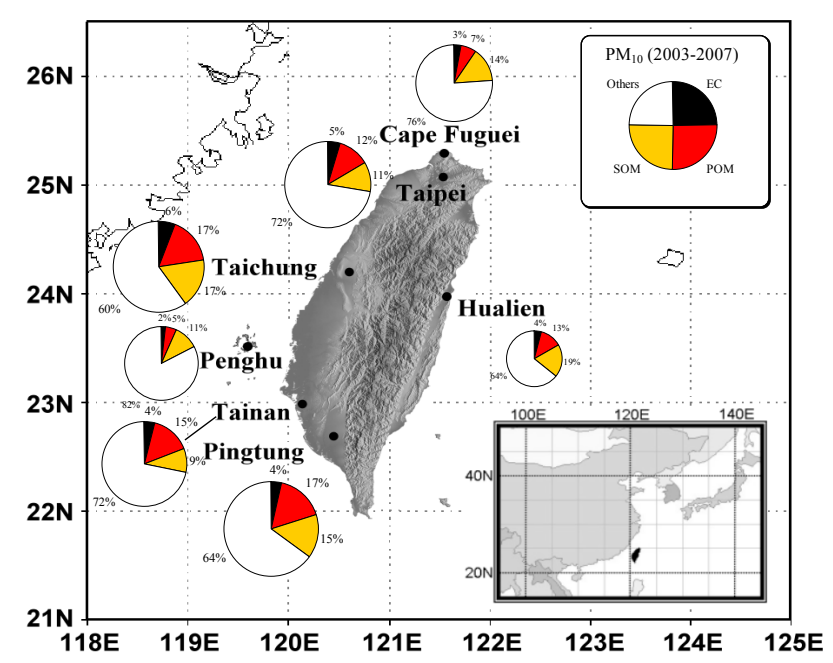

Fig. 4. Mean contributions of EC, POM, and SOM to the mass concentrations of $\mathrm{PM}_{10}$ at the respective stations over Taiwan from 2003 to 2007 . The area of each pie is proportional to the mass concentration.

are composed of highly oxidized species and the mass ratio of SOM/SOC may be significantly higher than that of POM/POC (e.g., Aiken et al., 2008; Donahue et al., 2009 and references cited therein). Turpin and Lim (2001) suggested a ratio of 1.3 for "less water soluble" organics and 3.2 for "more water soluble" organics. In this work, we further extended the assumptions of Turpin and Lim (2001) and applied different mass conversion factors to the calculation of SOM and POM. Considering that the POM are composed mostly of insoluble compounds and, in contrast, the oxidation products of photochemical reactions are usually soluble in water, the mass of POM was assumed being 1.3 times POC, whereas SOM was estimated as 3.2 times the SOC concentrations.

The strong contrast between the urban and the rural sites is obvious in Figs. 4-5. At the Cape Fuguei and Penghu, the $\mathrm{PM}_{10}$ and $\mathrm{PM}_{2.5}$ comprised only $2-3 \%$ and $3-5 \% \mathrm{EC}$, 
Table 2. Annual means of the $\mathrm{PM}_{10}$ and $\mathrm{PM}_{2.5}$ and the carbonaceous constituents measured at the respective stations from 2003 to 2007.

\begin{tabular}{|c|c|c|c|c|c|c|c|c|c|c|}
\hline & & & & & & & & & & $\mu \mathrm{gm}^{-3}$ \\
\hline & \multicolumn{5}{|c|}{$\mathrm{PM}_{10}$} & \multicolumn{5}{|c|}{$\mathrm{PM}_{2.5}$} \\
\hline \multicolumn{11}{|c|}{2003} \\
\hline Cape Fuguei & $52.4(2.6)$ & $1.5(0.1)$ & $2.5(0.2)$ & $2.3(0.1)$ & 77 & $29.2(1.7)$ & $1.3(0.1)$ & $2.3(0.2)$ & $1.6(0.1)$ & 73 \\
\hline Taipei & $63.3(3.1)$ & $3.4(0.2)$ & $6.3(0.3)$ & $1.6(0.2)$ & 38 & $40.8(3.0)$ & $3.1(0.2)$ & $4.7(0.4)$ & $1.4(0.2)$ & 27 \\
\hline Taichung & $61.4(3.5)$ & $4.7(0.3)$ & $9.6(0.5)$ & $4.1(0.5)$ & 51 & $45.3(3.0)$ & $3.9(0.3)$ & $6.4(0.5)$ & $3.1(0.5)$ & 39 \\
\hline Tainan & $73.3(5.3)$ & $3.4(0.2)$ & $8.8(0.3)$ & $2.1(0.3)$ & 41 & $45.3(3.6)$ & $3.1(0.2)$ & $6.2(0.4)$ & $1.9(0.2)$ & 30 \\
\hline Pingtung & $81.5(4.6)$ & $3.4(0.3)$ & $11.1(0.6)$ & $4.2(0.5)$ & 28 & $65.0(5.3)$ & $2.5(0.5)$ & $8.0(0.7)$ & $3.3(0.5)$ & 17 \\
\hline Penghu & $40.7(3.0)$ & $0.9(0.1)$ & $1.8(0.3)$ & $2.0(0.2)$ & 38 & 22.2(1.9) & $0.8(0.1)$ & $1.1(0.2)$ & $1.5(0.2)$ & 30 \\
\hline Hualien & $44.5(3.6)$ & $2.2(0.2)$ & $5.0(0.5)$ & $2.3(0.2)$ & 38 & $26.6(2.6)$ & $1.9(0.2)$ & $3.4(0.4)$ & $1.0(0.3)$ & 27 \\
\hline \multicolumn{11}{|c|}{2004} \\
\hline Cape Fuguei & $57.4(4.4)$ & $1.1(0.1)$ & $1.9(0.2)$ & $3.8(0.3)$ & 47 & $29.6(2.1)$ & $1.0(0.1)$ & $1.8(0.2)$ & $2.7(0.2)$ & 38 \\
\hline Taipei & $56.2(6.3)$ & $2.9(0.3)$ & $5.3(0.5)$ & $3.3(0.7)$ & 21 & $38.0(4.1)$ & $2.9(0.3)$ & $4.5(0.6)$ & $3.2(0.3)$ & 14 \\
\hline Taichung & $78.0(6.8)$ & $4.1(0.4)$ & $8.7(0.6)$ & $5.8(0.6)$ & 44 & $58.6(5.6)$ & $4.0(0.4)$ & $6.6(0.7)$ & $5.6(0.6)$ & 39 \\
\hline Tainan & $80.2(8.8)$ & $3.5(0.4)$ & $9.0(0.6)$ & $2.7(0.5)$ & 13 & $61.7(7.7)$ & $2.9(0.4)$ & $5.9(0.7)$ & $3.5(0.4)$ & 10 \\
\hline Pingtung & $69.9(3.7)$ & $2.2(0.2)$ & $8.9(0.3)$ & $4.0(0.4)$ & 29 & $58.9(3.5)$ & $2.3(0.1)$ & $7.7(0.2)$ & $4.1(0.5)$ & 28 \\
\hline Penghu & $54.9(2.6)$ & $0.8(0.1)$ & $1.8(0.1)$ & $1.9(0.1)$ & 53 & 26.6(1.9) & $0.9(0.1)$ & $1.3(0.2)$ & $1.5(0.1)$ & 34 \\
\hline Hualien & $36.0(2.2)$ & $1.5(0.1)$ & $3.4(0.3)$ & $3.1(0.2)$ & 52 & 19.3(1.3) & $1.2(0.1)$ & $2.1(0.2)$ & $2.1(0.1)$ & 45 \\
\hline \multicolumn{11}{|c|}{2005} \\
\hline Cape Fuguei & $45.7(2.9)$ & $1.4(0.1)$ & $2.4(0.2)$ & $2.8(0.2)$ & 48 & $31.7(2.6)$ & $1.5(0.1)$ & $2.6(0.2)$ & $1.9(0.2)$ & 34 \\
\hline Taipei & $60.1(6.9)$ & $3.8(0.2)$ & $7.0(0.4)$ & $1.8(0.4)$ & 21 & $48.4(7.2)$ & $3.6(0.3)$ & $5.7(0.5)$ & $1.8(0.3)$ & 12 \\
\hline Taichung & $73.7(4.7)$ & $4.0(0.3)$ & $8.5(0.4)$ & $3.4(0.4)$ & 50 & $47.2(4.3)$ & $3.2(0.2)$ & $5.2(0.4)$ & $2.6(0.2)$ & 34 \\
\hline Tainan & $70.3(5.7)$ & $2.7(0.3)$ & $7.8(0.4)$ & $1.5(0.3)$ & 27 & $48.5(4.2)$ & $2.5(0.3)$ & $5.0(0.5)$ & $1.8(0.3)$ & 20 \\
\hline Pingtung & $77.3(4.4)$ & $2.6(0.2)$ & $9.5(0.4)$ & $3.8(1.0)$ & 13 & $62.6(4.1)$ & $2.3(0.2)$ & $7.8(0.3)$ & $3.3(0.7)$ & 13 \\
\hline Penghu & $44.3(2.2)$ & $1.0(0.1)$ & $2.0(0.1)$ & $2.2(0.3)$ & 70 & $24.2(1.4)$ & $0.9(0.1)$ & $1.4(0.1)$ & $1.3(0.1)$ & 56 \\
\hline Hualien & $41.0(2.9)$ & $1.9(0.1)$ & $4.4(0.3)$ & $2.6(0.2)$ & 57 & 24.7(1.9) & $1.6(0.1)$ & $2.9(0.2)$ & $2.1(0.2)$ & 51 \\
\hline \multicolumn{11}{|c|}{2006} \\
\hline Cape Fuguei & $46.7(3.7)$ & $1.6(0.1)$ & $2.6(0.2)$ & $1.4(0.2)$ & 52 & 23.7(1.9) & $0.9(0.1)$ & $1.7(0.2)$ & $1.1(0.1)$ & 38 \\
\hline Taipei & $65.8(4.6)$ & $3.2(0.3)$ & $6.0(0.4)$ & $2.4(0.3)$ & 36 & $40.9(3.3)$ & $3.3(0.3)$ & $5.2(0.5)$ & $2.2(0.4)$ & 28 \\
\hline Taichung & $66.7(5.0)$ & $4.5(0.4)$ & $9.3(0.5)$ & $3.0(0.5)$ & 19 & 44.3(3.9) & $3.5(0.3)$ & $5.8(0.5)$ & $2.5(0.3)$ & 28 \\
\hline Tainan & $68.5(3.3)$ & $3.5(0.4)$ & $9.0(0.7)$ & $1.9(0.5)$ & 7 & - & - & - & - & 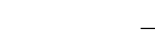 \\
\hline Pingtung & $78.9(4.8)$ & $2.7(0.2)$ & $9.8(0.3)$ & $3.3(0.5)$ & 39 & $51.2(2.6)$ & $2.4(0.1)$ & $7.8(0.2)$ & $2.1(0.3)$ & 39 \\
\hline Penghu & $45.6(2.9)$ & $0.8(0.1)$ & $1.7(0.1)$ & $0.9(0.1)$ & 62 & 23.2(1.6) & $0.7(0.1)$ & $1.0(0.1)$ & $0.7(0.1)$ & 60 \\
\hline Hualien & $37.4(2.6)$ & $1.4(0.1)$ & $3.3(0.2)$ & $2.4(0.1)$ & 59 & 21.6(1.8) & $1.5(0.1)$ & $2.7(0.2)$ & $1.3(0.1)$ & 31 \\
\hline \multicolumn{11}{|c|}{2007} \\
\hline Cape Fuguei & $47.0(3.0)$ & $1.9(0.2)$ & $3.2(0.3)$ & $1.3(0.1)$ & 64 & $26.2(1.9)$ & $1.5(0.1)$ & $2.6(0.2)$ & $1.0(0.1)$ & 59 \\
\hline Taipei & $63.4(3.5)$ & $2.5(0.1)$ & $4.8(0.2)$ & $2.2(0.1)$ & 66 & $39.8(2.1)$ & $2.5(0.1)$ & $3.8(0.2)$ & $2.0(0.1)$ & 61 \\
\hline Taichung & $67.5(4.7)$ & $3.9(0.3)$ & $8.5(0.4)$ & $2.5(0.6)$ & 54 & $43.8(4.0)$ & $3.7(0.3)$ & $6.1(0.5)$ & $2.7(0.5)$ & 48 \\
\hline Tainan & $67.0(6.1)$ & $2.5(0.2)$ & $7.5(0.3)$ & $2.0(0.5)$ & 22 & $59.9(6.2)$ & $2.6(0.2)$ & $5.3(0.4)$ & $3.6(0.8)$ & 11 \\
\hline Pingtung & $62.9(9.8)$ & $2.2(0.3)$ & $8.8(0.6)$ & $1.1(0.5)$ & 14 & $46.7(5.6)$ & $2.0(0.3)$ & $7.3(0.4)$ & $1.0(0.5)$ & 20 \\
\hline Penghu & $43.7(2.5)$ & $0.9(0.1)$ & $1.8(0.1)$ & $0.9(0.1)$ & 77 & $21.5(1.5)$ & $0.7(0.1)$ & $1.1(0.1)$ & $0.7(0.1)$ & 75 \\
\hline Hualien & $39.5(1.2)$ & $1.6(0.1)$ & $3.5(0.2)$ & $1.5(0.1)$ & 70 & 18.2(1.5) & $1.4(0.1)$ & $2.5(0.2)$ & $0.9(0.1)$ & 70 \\
\hline
\end{tabular}

The standard error of each mean value is noted in parentheses.

respectively. However, in the urban areas, the EC fractions increased to 4-6\% for $\mathrm{PM}_{10}$, and 4-8\% for $\mathrm{PM}_{2.5}$. The spatial distribution of POM also showed the inherent urban-rural contrast clearly. POM contributed $5-7 \%$ and $7-10 \%$ to the mass of $\mathrm{PM}_{10}$ and $\mathrm{PM}_{2.5}$, respectively, at rural sites, and increased by a factor of $2-3$ in the urban areas. Thus, in to- tal, the primary carbonaceous aerosols accounted for $7-10 \%$ and $10-15 \%$ of the $\mathrm{PM}_{10}$ and $\mathrm{PM}_{2.5}$ in the rural areas, respectively, comparing to $17-23 \%$ and $21-25 \%$ in the urban areas. On the contrary, SOM did not exhibit such a contrast. For instance, the contribution of SOM to the aerosol mass loading at the Cape Fuguei was comparable with that in the 


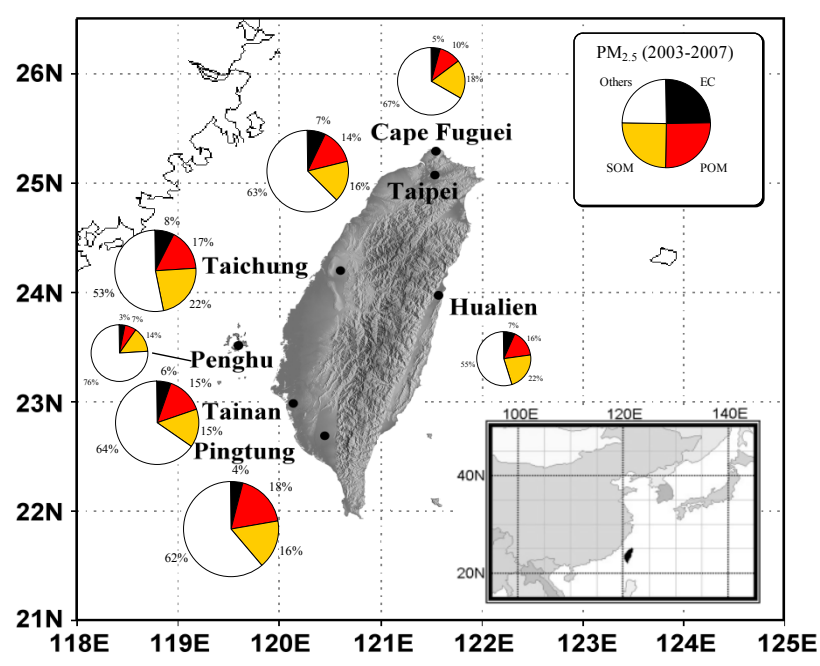

Fig. 5. Same as Fig. 4 but for $\mathrm{PM}_{2.5}$.

Metropolis Taipei (14\% vs. $11 \%$ for $\mathrm{PM}_{10} ; 18 \%$ vs. $16 \%$ for $\mathrm{PM}_{2.5}$ ). Moreover, in contrast to the lowest $\mathrm{PM}_{10}$ and $\mathrm{PM}_{2.5}$ levels among the stations, the SOM contribution was highest in Hualien that reached $19 \%$ to $\mathrm{PM}_{10}$ and $22 \%$ to $\mathrm{PM}_{2.5}$.

The major implication of the observed urban-rural contrast in the carbonaceous aerosols' concentrations is that the influences of the primary aerosols (e.g., EC and POM) should be confined on urban scales and hence highly heterogeneous over a region. Although the long-range transport of aerosols from mega-cities to the remote areas indeed occurred, the dry/wet deposition and dispersion processes along the transport could have reduced the aerosol concentrations significantly. Consequently, the impacts of the primary aerosols on either the public health or the solar irradiances should have a very strong gradient declining from the megacities to their surrounding rural areas. This is particularly an issue of regional climate because the aerosols could thereby cause significant differences in the surface irradiance and, in turn, could have disturbed the local circulation of air mass. The influences of SOA seem being more homogeneous spatially. However, the production of SOA is much more complicated than the emission of primary aerosols. The molecular composition of the SOA in rural areas could be essentially different from that in urban areas, despite the mass concentrations were comparable. Thus, in this context, the contribution of the anthropogenic precursors in urban plumes to the production of SOA in the downwind areas cannot be estimated based merely on the traditional OC/EC measurement.

\section{Seasonal variations of the carbonaceous aerosols}

To depict the seasonality of the carbonaceous aerosols in Taiwan, the dataset was reanalyzed in terms of seasonal mean and the results are listed in Table 3. The periods of spring, summer, and autumn start from the 1 March, June, and September, respectively; winter is from December to the February of next year. Figure 6 illustrates the seasonal variations in the mass concentrations of $\mathrm{PM}_{10}$ and the associated carbonaceous components, respectively, at the network stations. Because the carbonaceous aerosols were mostly confined in the fine mode, the seasonal features of the carbonaceous constituents of $\mathrm{PM}_{2.5}$ are similar with those of $\mathrm{PM}_{10}$ and, therefore, are not illustrated here. The seasonal means of $\mathrm{CO}$ and the daily maximal 1-h oxidant (estimated by $\mathrm{O}_{3}+\mathrm{NO}_{2}$ ) mixing ratios, which were respectively used as indicators of primary and secondary pollution, are also shown in Fig. 6 to facilitate the following discussion.

The stations in northern Taiwan (Cape Fuguei and Taipei) showed consistent seasonality in the concentrations of OC (both POC and SOC) and EC. The concentrations of all the three components reached their respective minima in the fall season and, then, increased drastically in the wintertime. The autumn minima of the carbonaceous aerosols were consistent with $\mathrm{CO}$ and $\mathrm{Ox} \_\max$, but disagreed with the $\mathrm{PM}_{10}$ levels. The reduced level of air pollution in the fall season in Taipei was most likely a consequence of meteorological conditions that favored dispersion of air pollutants. The 30 -year statistics of the monthly averages of wind speed, surface temperature, and sunshine hours from Taiwan CWB's Taipei station are illustrated in the supplemental Fig. S1. The disagreement between $\mathrm{PM}_{10}$ and $\mathrm{CO}$ (and EC) suggests probable contribution from non-combustion sources. Chou et al. (2008) reported that sea-salt and dust particles contributed a large portion of the aerosol mass in northern Taiwan during the periods of northeasterly monsoons that started from autumn.

Except SOC, all the species presented in Fig. 6a-b showed spring maxima. Note that, in summertime, the primary pollutants' concentrations decreased significantly from their respective spring maxima, whereas the secondary species remained or even increased slightly. In fact, SOC exhibited a bimodal pattern with the maximum in winter and the second mode in summer. The high SOC levels observed in the northern Taiwan in summertime were consistent with the elevated oxidant levels, implying that the in-situ photochemical production of secondary organic aerosols was prevailing. However, the occurrence of the winter maxima was contradictory in this context. Given that the UV irradiance over the subtropics is still enough to support substantial photochemical reactions in wintertime, the drastic increases in the SOC concentrations from autumn to winter was probably a result of declined ambient temperature. Strader et al. (1999) showed that the partition between gas and aerosol phases of SOA compounds can be influenced by the ambient temperature. Statistics over 1971-2000 shows that the monthly average temperature in Taipei ranged from $15.8^{\circ} \mathrm{C}$ in January to $29.2^{\circ} \mathrm{C}$ in July (shown in Fig. S1), just being coincident with the temperature window where the SOA phase partition is most sensitive to temperature. 
Table 3. Seasonal means of the mass concentrations of EC, POC and SOC for 2003-2007.

\begin{tabular}{|c|c|c|c|c|c|c|c|c|c|c|}
\hline & & & & & & & & & & $\mu \mathrm{gm}^{-3}$ \\
\hline & \multicolumn{5}{|c|}{$\mathrm{PM}_{10}$} & \multicolumn{5}{|c|}{$\mathrm{PM}_{2.5}$} \\
\hline & $\mathrm{PM}_{10}$ & $\mathrm{EC}$ & POC & SOC & Sample No. & $\mathrm{PM}_{2.5}$ & $\mathrm{EC}$ & POC & SOC & Sample No. \\
\hline \multicolumn{11}{|c|}{ Spring } \\
\hline Cape Fuguei & $59.5(2.9)$ & $1.7(0.1)$ & $2.8(0.2)$ & $2.2(0.1)$ & 77 & $33.1(1.6)$ & $1.5(0.1)$ & $2.6(0.2)$ & $1.7(0.1)$ & 69 \\
\hline Taipei & $74.4(3.3)$ & $3.7(0.1)$ & $6.7(0.3)$ & $2.2(0.2)$ & 63 & $47.5(2.4)$ & $3.4(0.1)$ & $5.3(0.2)$ & $2.1(0.2)$ & 59 \\
\hline Taichung & $73.4(4.3)$ & $3.9(0.2)$ & $8.4(0.3)$ & $3.1(0.3)$ & 56 & $54.4(3.6)$ & $3.4(0.2)$ & $5.7(0.3)$ & $2.5(0.2)$ & 48 \\
\hline Tainan & $81.9(4.1)$ & $3.4(0.2)$ & $8.9(0.3)$ & $1.1(0.2)$ & 29 & $53.1(3.4)$ & $2.9(0.2)$ & $5.9(0.4)$ & $1.2(0.2)$ & 21 \\
\hline Pingtung & $72.0(3.4)$ & $2.7(0.2)$ & $9.7(0.3)$ & $3.4(0.3)$ & 42 & $48.3(2.9)$ & $2.1(0.1)$ & $7.4(0.2)$ & $2.0(0.3)$ & 32 \\
\hline Penghu & $51.3(2.9)$ & $0.9(0.1)$ & $1.9(0.1)$ & $1.3(0.2)$ & 80 & $26.4(1.6)$ & $0.8(0.1)$ & $1.2(0.1)$ & $0.9(0.1)$ & 79 \\
\hline Hualien & $42.8(2.4)$ & $1.6(0.1)$ & $3.7(0.2)$ & $2.3(0.1)$ & 74 & 24.1(1.4) & $1.6(0.1)$ & $2.8(0.1)$ & $1.2(0.1)$ & 67 \\
\hline \multicolumn{11}{|c|}{ Summer } \\
\hline Cape Fuguei & $31.8(1.1)$ & $1.7(0.1)$ & $2.7(0.1)$ & $2.4(0.2)$ & 73 & $19.6(0.9)$ & $1.1(0.1)$ & $2.0(0.1)$ & $1.5(0.1)$ & 56 \\
\hline Taipei & $48.9(2.7)$ & $3.1(0.2)$ & $5.7(0.3)$ & $2.6(0.3)$ & 33 & $38.0(2.4)$ & $3.0(0.2)$ & $4.7(0.4)$ & $2.2(0.3)$ & 25 \\
\hline Taichung & $44.3(2.7)$ & $3.1(0.3)$ & $7.3(0.5)$ & $4.6(0.7)$ & 37 & $31.0(2.7)$ & $2.3(0.2)$ & $3.8(0.4)$ & $4.9(0.8)$ & 25 \\
\hline Tainan & $38.5(5.1)$ & $1.8(0.2)$ & $6.3(0.3)$ & $1.3(0.3)$ & 19 & $30.3(5.3)$ & $1.9(0.2)$ & $4.0(0.4)$ & $2.2(0.1)$ & 8 \\
\hline Pingtung & $45.5(2.8)$ & $1.4(0.2)$ & $7.5(0.4)$ & $4.6(0.9)$ & 13 & $34.8(2.3)$ & $1.4(0.2)$ & $6.3(0.2)$ & $3.8(0.9)$ & 11 \\
\hline Penghu & $29.0(1.4)$ & $0.7(0.1)$ & $1.5(0.1)$ & $2.1(0.2)$ & 59 & $16.9(1.1)$ & $0.6(0.1)$ & $0.9(0.1)$ & $1.1(0.1)$ & 44 \\
\hline Hualien & $30.1(1.7)$ & $1.5(0.1)$ & $3.5(0.1)$ & $2.9(0.3)$ & 48 & $16.3(1.7)$ & $1.2(0.1)$ & $2.1(0.1)$ & $1.5(0.2)$ & 39 \\
\hline \multicolumn{11}{|c|}{ Autumn } \\
\hline Cape Fuguei & $52.1(3.5)$ & $1.1(0.1)$ & $1.9(0.2)$ & $1.5(0.2)$ & 67 & $25.6(2.1)$ & $1.0(0.1)$ & $1.8(0.2)$ & $1.1(0.1)$ & 59 \\
\hline Taipei & $51.6(3.4)$ & $2.2(0.2)$ & $4.2(0.3)$ & $1.5(0.2)$ & 47 & $31.1(2.8)$ & $2.3(0.2)$ & $3.4(0.4)$ & $1.7(0.2)$ & 30 \\
\hline Taichung & $70.0(4.3)$ & $4.6(0.3)$ & $9.5(0.5)$ & $3.9(0.6)$ & 62 & $40.8(3.3)$ & $3.7(0.2)$ & $6.1(0.4)$ & $3.3(0.4)$ & 58 \\
\hline Tainan & $73.3(3.9)$ & $3.1(0.2)$ & $8.4(0.3)$ & $2.6(0.4)$ & 38 & $52.1(3.6)$ & $3.0(0.2)$ & $6.1(0.4)$ & $2.9(0.4)$ & 30 \\
\hline Pingtung & $65.0(3.0)$ & $2.8(0.2)$ & $9.9(0.3)$ & $3.6(0.8)$ & 27 & $47.1(2.2)$ & $2.2(0.2)$ & $7.6(0.3)$ & $2.5(0.5)$ & 23 \\
\hline Penghu & $47.4(1.7)$ & $0.8(0.1)$ & $1.7(0.1)$ & $1.6(0.1)$ & 81 & $21.9(1.3)$ & $0.7(0.1)$ & $1.1(0.1)$ & $1.1(0.1)$ & 74 \\
\hline Hualien & $39.0(2.1)$ & $1.5(0.1)$ & $3.4(0.2)$ & $2.3(0.1)$ & 86 & $18.8(1.6)$ & $1.3(0.1)$ & $2.2(0.2)$ & $1.4(0.1)$ & 65 \\
\hline \multicolumn{11}{|c|}{ Winter } \\
\hline Cape Fuguei & $56.0(2.7)$ & $1.6(0.1)$ & $2.7(0.2)$ & $2.9(0.2)$ & 71 & $32.5(1.8)$ & $1.4(0.1)$ & $2.4(0.2)$ & $2.0(0.2)$ & 58 \\
\hline Taipei & $68.7(4.7)$ & $3.0(0.2)$ & $5.6(0.4)$ & $2.8(0.4)$ & 39 & $39.3(2.9)$ & $2.5(0.2)$ & $3.8(0.4)$ & $2.2(0.2)$ & 28 \\
\hline Taichung & $80.5(4.7)$ & $4.7(0.3)$ & $9.7(0.4)$ & $3.8(0.5)$ & 63 & $57.0(3.9)$ & $4.6(0.3)$ & $7.5(0.5)$ & $3.4(0.5)$ & 54 \\
\hline Tainan & $83.7(7.1)$ & $3.6(0.3)$ & $9.2(0.5)$ & $2.6(0.4)$ & 24 & $57.0(8.0)$ & $2.6(0.3)$ & $5.2(0.7)$ & $2.7(0.4)$ & 12 \\
\hline Pingtung & $95.1(4.0)$ & $3.0(0.2)$ & $10.3(0.4)$ & $3.1(0.3)$ & 41 & $72.1(2.6)$ & $2.9(0.2)$ & $8.6(0.3)$ & $3.3(0.4)$ & 44 \\
\hline Penghu & $51.0(2.1)$ & $1.0(0.1)$ & $2.1(0.1)$ & $1.2(0.1)$ & 80 & $25.6(1.4)$ & $0.9(0.1)$ & $1.4(0.1)$ & $1.0(0.1)$ & 58 \\
\hline Hualien & $43.2(2.6)$ & $2.1(0.1)$ & $4.8(0.3)$ & $2.0(0.2)$ & 68 & $24.8(1.7)$ & $1.9(0.1)$ & $3.4(0.2)$ & $1.9(0.2)$ & 53 \\
\hline \multicolumn{11}{|c|}{ Whole Year } \\
\hline Cape Fuguei & $49.9(1.5)$ & $1.5(0.1)$ & $2.5(0.1)$ & $2.3(0.1)$ & 288 & $28.0(0.9)$ & $1.3(0.1)$ & $2.2(0.1)$ & $1.6(0.1)$ & 242 \\
\hline Taipei & $62.6(2.0)$ & $3.0(0.1)$ & $5.6(0.2)$ & $2.2(0.1)$ & 182 & $40.8(1.4)$ & $2.9(0.1)$ & $4.5(0.2)$ & $2.1(0.1)$ & 142 \\
\hline Taichung & $69.5(2.3)$ & $4.2(0.1)$ & $8.9(0.2)$ & $3.8(0.3)$ & 218 & $47.9(2.0)$ & $3.7(0.1)$ & $6.1(0.2)$ & $3.4(0.2)$ & 185 \\
\hline Tainan & $73.0(2.9)$ & $3.1(0.1)$ & $8.3(0.2)$ & $2.0(0.2)$ & 110 & $50.8(2.5)$ & $2.8(0.1)$ & $5.7(0.3)$ & $2.3(0.2)$ & 71 \\
\hline Pingtung & $75.4(2.4)$ & $2.7(0.1)$ & $9.7(0.2)$ & $3.5(0.2)$ & 123 & $55.5(1.8)$ & $2.4(0.1)$ & $7.8(0.2)$ & $2.8(0.2)$ & 110 \\
\hline Penghu & $45.8(1.2)$ & $0.9(<0.1)$ & $1.8(0.1)$ & $1.5(0.1)$ & 300 & $23.3(0.7)$ & $0.8(<0.1)$ & $1.2(0.1)$ & $1.0(0.1)$ & 255 \\
\hline Hualien & $39.5(1.2)$ & $1.7(0.1)$ & $3.8(0.1)$ & $2.3(0.1)$ & 276 & $21.4(0.8)$ & $1.5(0.1)$ & $2.6(0.1)$ & $1.5(0.1)$ & 224 \\
\hline
\end{tabular}

The standard error of each mean value is noted in parentheses.

In contrast to the spring maxima observed at the two northern sites, the other 5 stations over the central and southern Taiwan exhibited winter maxima in $\mathrm{PM}_{10}, \mathrm{CO}, \mathrm{EC}$, and POC (shown in Fig. 6c-g). The winter maxima are typical in terms of pollution meteorology; the shallow mixing layer and the formation of surface inversion could have inhibited the dis- persion of air pollutants in that season. In addition, episodic burning of agricultural residues was also contributing to the elevated levels of carbonaceous aerosols in the central and southern Taiwan during harvest seasons, from late autumn to early winter (Chio et al., 2004). Quantitative analyses on the influences of meteorology and agricultural biomass burning 

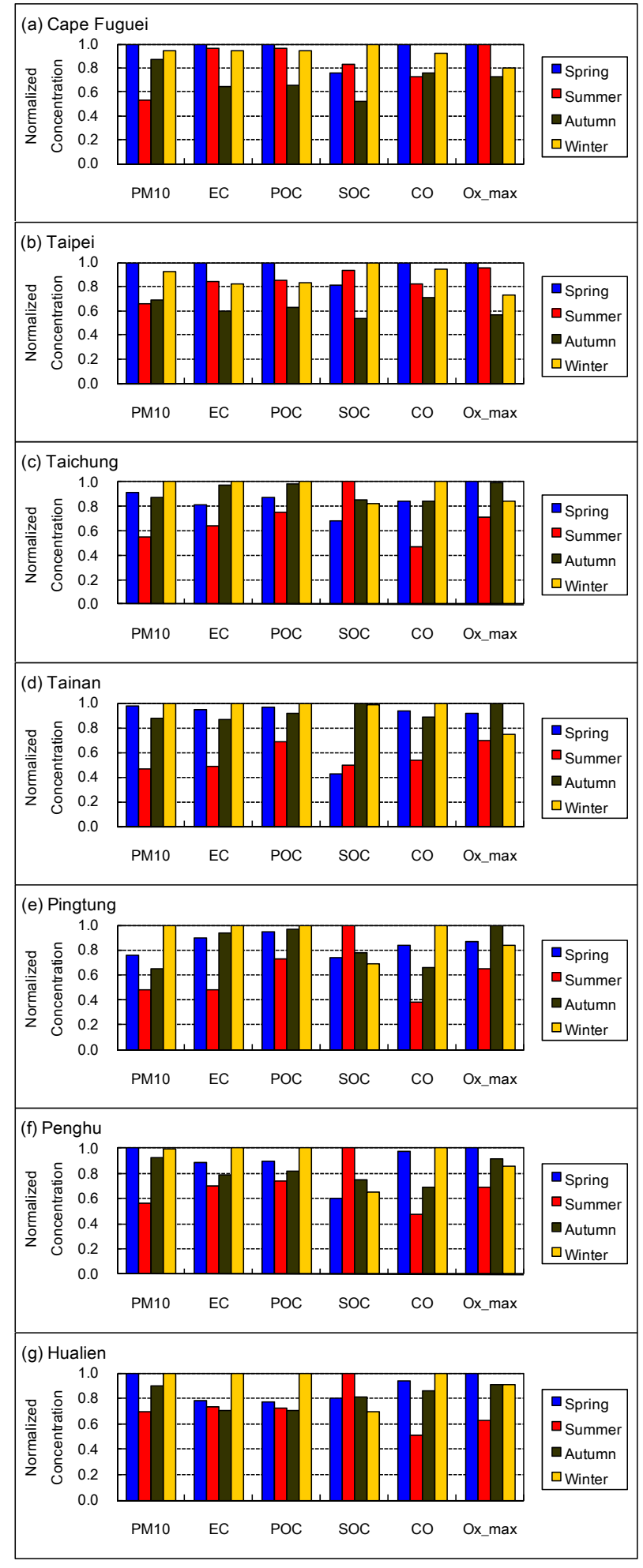

Fig. 6. Seasonal variations in the mass concentrations of carbonaceous components of $\mathrm{PM}_{10}$ at the respective network stations. The variations in $\mathrm{PM}_{10}, \mathrm{CO}$, and daily oxidant maximum (Ox_max) are illustrated for reference. Note that, for the purpose of visualization, the seasonality of each species is illustrated in terms of normalized concentration.
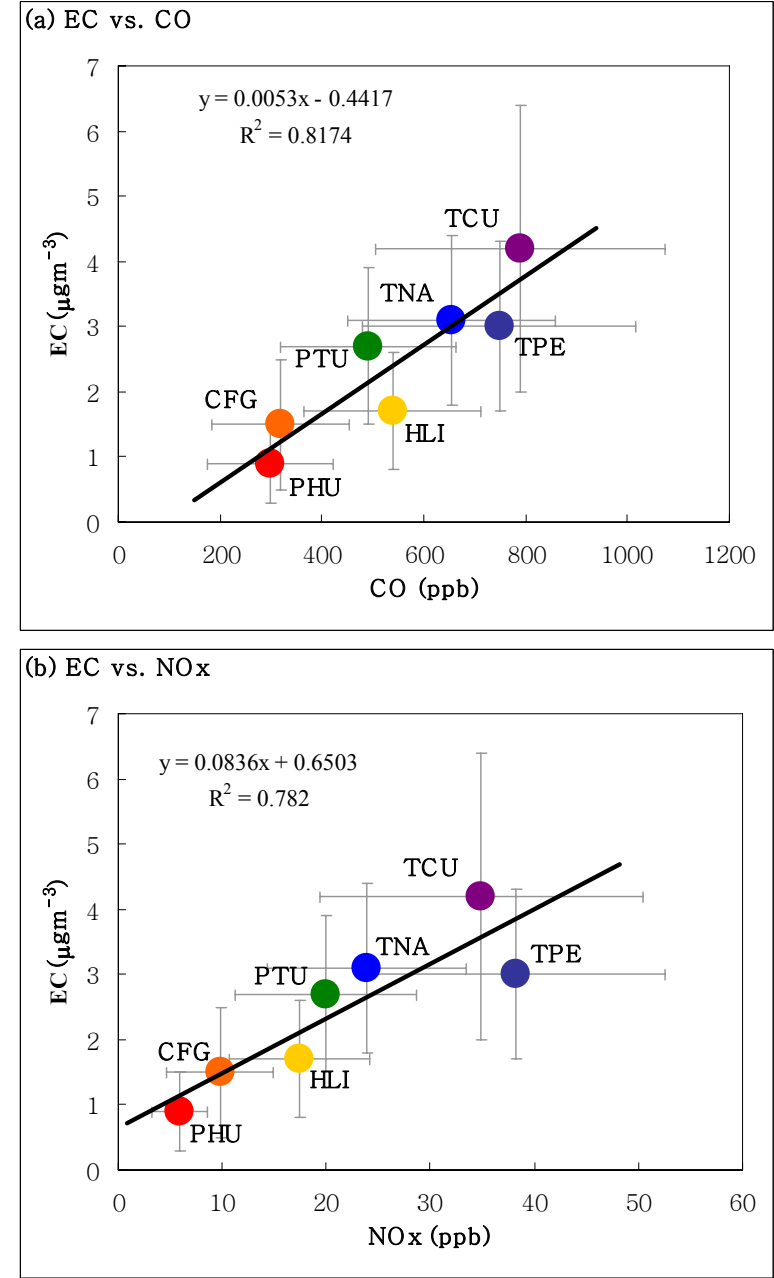

Fig. 7. Correlations between EC and CO (a), and between EC and $\mathrm{NO}_{\mathrm{x}}$ (b) across the network stations. The symbols for respective stations were color-coded to assist comparison among (a)-(b) and Fig. 8a-c.

will be made in further studies. Thus the maxima of the $\mathrm{PM}_{10}, \mathrm{CO}$, and oxidant in northern Taiwan during springtime need to be explained. Recent investigations showed that the transport of air pollutants originating in China could have increased the concentrations of air pollutants in the region of Northwestern Pacific (e.g., Hoell et al., 1997; Jacob et al., 2003; Huebert et al., 2003). Lin et al. (2005) further showed that the influences of the Asian outflows on the air quality in Taiwan were declining from north to south. Moreover, observation based modeling studies showed that the Asian pollution outflow was most prevailing in springtime (Liu et al., 2003). Accordingly, it was inferred that the long-range transport of air pollutants from China could have shifted the maxima of the concentrations of air pollutants from winter to spring in the northern Taiwan. 
The SOC reached maxima in summer in Taichung, Pingtung, Penghu, and Hualien (the only exception of Tainan is unclear yet). It is noteworthy that the oxidant exhibited summer minima at the 5 stations. Besides oxidant, the concentrations of major primary air pollutants (including the anthropogenic precursors of SOA) should have also been decreased significantly in summer for the meteorological conditions, as indicated by $\mathrm{CO}$ in Fig. 6. The strong convection in summertime can strengthen the dispersion and, consequently, reduce the mixing ratios of ozone as well as the other air pollutants. Thus, the summer maxima of SOA indicate that the seasonal enhancement of the production of SOA in summertime overcame the dispersion effects. Considering the decreased oxidant and anthropogenic precursors, the enhancement in the SOA production was most likely a result of the increases in the emissions of biogenic VOCs, which also show strong seasonality with summer maxima. In addition to the influences of precursors, the SOA production is known being dependent on ambient temperature and relative humidity (Strader et al., 1999; Seinfeld et al., 2001; Russell and Allen, 2005). The weather conditions in summer are doubtlessly favorable to the SOA yield and, in turn, to the formation of summer maxima of SOA levels.

\section{Correlation between carbonaceous aerosols and trace gases}

Despite that the concentration of carbonaceous aerosols has been recognized as one of the key variables for the studies of air quality and atmospheric composition, it is not a commonly available measurement. A robust correlation between the aerosol components and the trace gases could be applied to estimate the levels of OC and EC from the trace gases that are regularly measured at the official air quality stations. Furthermore, the estimates could constrain the simulation of aerosols in modeling studies and, as a consequence, make the assessment of aerosols' effects more reasonable.

Figure $7 \mathrm{a}-\mathrm{b}$ show scatter plots for the 5-year means of $\mathrm{EC}$ vs. $\mathrm{CO}$ and $\mathrm{NO}_{\mathrm{x}}$, respectively. The slope of the regression line of $\mathrm{EC}$ vs. $\mathrm{CO}$ is $0.0053 \mu \mathrm{gC} \mathrm{m}{ }^{-3} / \mathrm{ppbv}$, which is comparable with the results of previous investigations. In Mexico City, for instance, Yu et al. (2009) found strong linear correlation between $\mathrm{EC}$ and $\mathrm{CO}$ with an average slope of 0.004. Chen et al. (2001) reported EC/CO slopes ranging from 0.003 to 0.007 for the Baltimore-Washington region. Besides, $\mathrm{EC} / \mathrm{CO}$ slopes of $\sim 0.005 \mu \mathrm{gC} \mathrm{m}{ }^{-3} / \mathrm{ppbv}$ were also observed in Gwangju, Tokyo, and Beijing (Park et al., 2005; Kondo et al, 2006; Han et al., 2009). Although the EC/CO slope is controlled by multi-factors, the values observed in various cities are surprisingly consistent. Note that the correlation shown in Fig. 7a was derived from the measurements of a network consisting of seven stations. Such a cross station correlation suggests that the ambient levels of $\mathrm{CO}$ and EC were dominated by similar sources over Taiwan, and maybe in many of the developed urban areas worldwide. In contrast to the well documented correlation between $\mathrm{CO}$ and $\mathrm{EC}$, the correlation between $\mathrm{NO}_{\mathrm{x}}$ and $\mathrm{EC}$ seems to be relatively overlooked in previous studies. Given the short lifetime of $\mathrm{NO}_{\mathrm{x}}$ in the lower troposphere, a strong correlation between $\mathrm{EC}$ and $\mathrm{NO}_{\mathrm{x}}$ is an indication of that the EC-containing aerosols should be emitted mostly from local sources. Indeed, Fig. 7b depicts the linear correlation between EC and $\mathrm{NO}_{\mathrm{x}}$ over Taiwan. The $\mathrm{EC} / \mathrm{NO}_{\mathrm{x}}$ slope suggests an emission ratio of $0.0836 \mu \mathrm{gC} \mathrm{m}{ }^{-3} / \mathrm{ppbv}$ in Taiwan. Furthermore, the intercept of the regression line gives an EC concentration of $0.65 \mu \mathrm{gC} \mathrm{m}^{-3}$ for $\mathrm{NO}_{\mathrm{x}}=0$, which could be corresponding to the regional background EC level without contribution from local sources.

Figure 8a illustrates the correlation between the SOC and the total oxidant. This result agrees with previous investigations (e.g., Yu et al., 2009), and was as expected because the SOA were produced from the oxidation of the precursors (i.e. gaseous hydrocarbons). The strong correlation shown in Fig. 8a suggests that the spatial distribution of SOC was dominated by the level of oxidant. Note that the observation of Tainan was treated as an outlier in the regression analysis. Figure $8 \mathrm{~b}-\mathrm{c}$ show the results of the regression analysis for nitrate vs. oxidant and SOC vs. nitrate. Note that SOC, oxidant, and nitrate exhibited strong north-south contrast over the western Taiwan, implying a common controlling mechanism. In an urban area, the formation of nitrate aerosols is usually dominated by the density of $\mathrm{OH}$ radicals. Given that the photolysis of ozone is the major source of $\mathrm{OH}$ radicals in urban troposphere, the consistency between particulate nitrate and the oxidant shown in Fig. $8 \mathrm{~b}$ is warrantable. Using the nitrate concentration as an independent check, Fig. 8c shows that the estimated SOC levels were agreeing with the prevalence of photochemical activities. Note that, similar to Fig. 8a, the observation of Tainan was also treated as an outlier here. Obviously, the correlations between SOC and both photochemical indicators suggest consistently that the SOC levels of Tainan could have been underestimated to a certain degree.

In addition to being a photochemical indicator, nitrate is also known as a surrogate of local pollution. The moderate correlation between SOC and nitrate $\left(R^{2}=0.64, p=0.05\right)$, as shown in Fig. 8c, implies that the SOA were mostly produced by oxidation of anthropogenic precursors emitted from local sources, particularly the motor vehicles. However, on the other hand, such a "moderate" correlation also suggests that there were other important factors (not relevant to nitrate formation) contributing to the variations in the SOC concentration. According to the observed seasonality of SOC and the relevant species, emission of biogenic precursors could be one of the probable factors that could influence the ambient levels of SOC. Besides, the changes in meteorological conditions could influence the yield and phase partition of SOA compounds. Note that the fundamental assumption of EC tracer method is on the correlation between POC and 


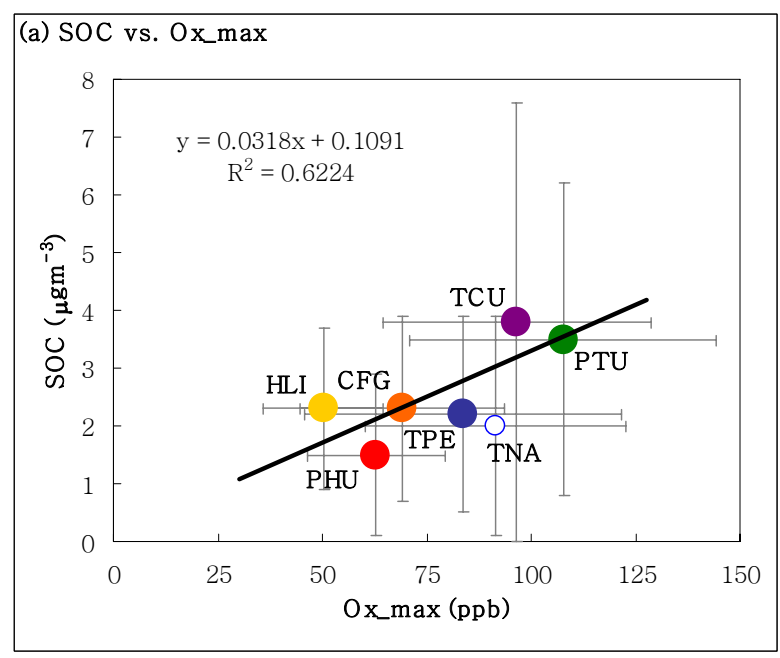

(b) Nitrate vs. Ox_max
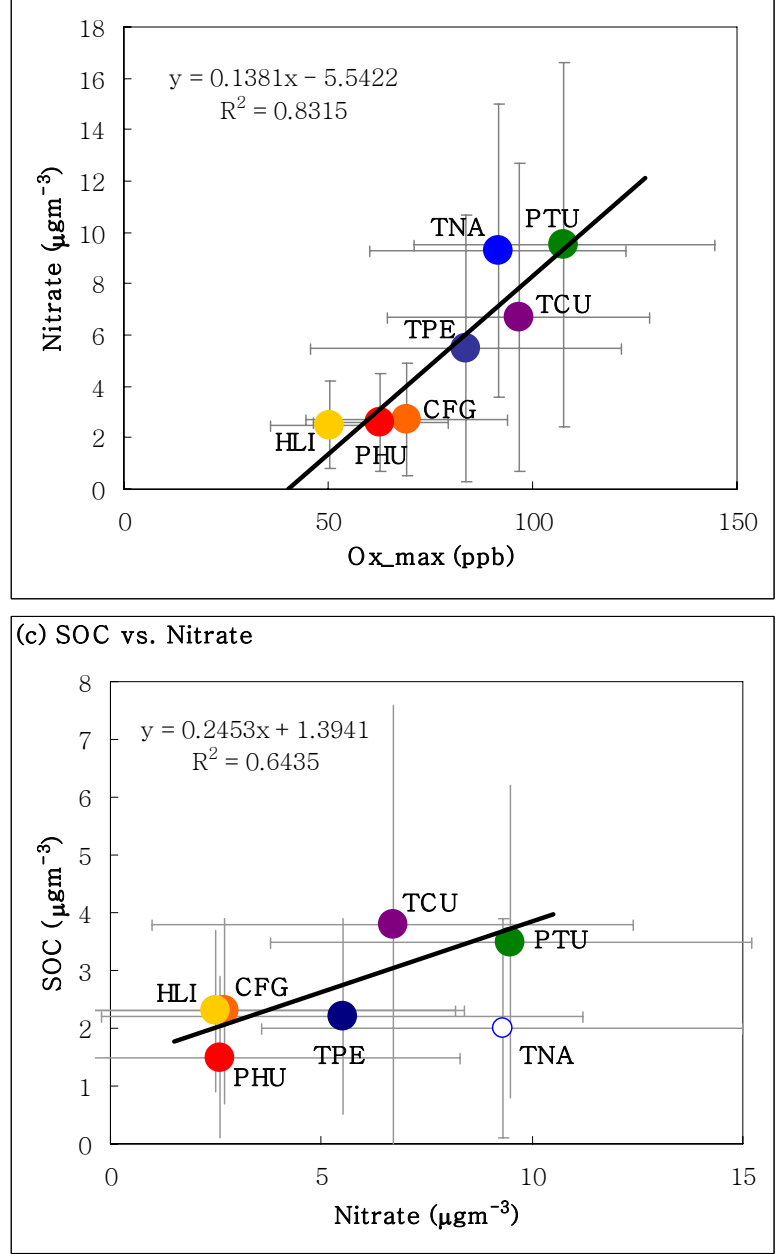

Fig. 8. Correlations between SOC and Ox_max (a), between particulate nitrate and Ox_max (b), and between SOC and $\mathrm{NO}_{\mathrm{x}}(\mathbf{c})$ across the network stations. The color coding of symbols are consistent with Fig. 7. The data of the Tainan station were treated as outliers in the linear regression processes and hence are shown as open symbols in panels (a) and (c).
EC. The associated SOC is simply the difference between the measured TOC and the estimated POC. In this context, this method is not able to distinguish between anthropogenic and biogenic components in the SOC. Further studies with molecular tracers are necessary to estimate the contribution in SOA formation from specific sources.

\section{Conclusions}

An observation network has been organized to investigate the concentration and composition of ambient aerosols in Taiwan since 2003. Analysis on the measurements of carbonaceous components in $\mathrm{PM}_{10}$ and $\mathrm{PM}_{2.5}$ from 2003 to 2007 showed that there was a very strong contrast between the rural and the urban/suburban areas.

The five-year means of EC ranged from $0.9 \pm 0.04 \mu \mathrm{gC} \mathrm{m}^{-3}$ at Penghu to $4.2 \pm 0.1 \mu \mathrm{gC} \mathrm{m}^{-3}$ at Taichung. Furthermore, it was found that the spatial distribution of EC was consistent with $\mathrm{CO}$ and $\mathrm{NO}_{\mathrm{x}}$ across the network stations. The strong cross station correlation between EC and CO suggests that the levels of EC over Taiwan were dominated by specific sources, most likely the vehicular exhausts. The slope of the EC vs. CO regression line was $0.0053 \mu \mathrm{gC} \mathrm{m} \mathrm{m}^{-3} / \mathrm{ppbv}$, agreeing with those observed in several megacities over the northern hemisphere. Given the relatively short lifetime of $\mathrm{NO}_{\mathrm{x}}$, the correlation between $\mathrm{EC}$ and $\mathrm{NO}_{\mathrm{x}}$ suggests that the EC-containing aerosols were emitted mostly from local sources. The emission ratio of $\mathrm{EC}$ to $\mathrm{NO}_{\mathrm{x}}$ and the regional background EC level were estimated to be $0.0836 \mu \mathrm{gC} \mathrm{m}^{-3} / \mathrm{ppbv}$ and $0.65 \mu \mathrm{gC} \mathrm{m}^{-3}$, respectively.

Applying EC tracer method, the measured OC was split into POC and SOC. The five-year means of POC ranged from $1.8 \pm 0.1 \mu \mathrm{gC} \mathrm{m}^{-3}$ at Penghu to $9.7 \pm 0.2 \mu \mathrm{gC} \mathrm{m}^{-3}$ at Pingtung. It was revealed that the characteristic POC/EC ratios were confined between 1.43 and 1.85 over the western Taiwan, whereas an elevated ratio of 2.36 was observed in the eastern Taiwan. This is most likely a consequence of the reduced amount of diesel vehicles in the eastern Taiwan. Moreover, it was also found that there was a substantial amount of organic aerosols originating from noncombustion sources in the major agricultural areas. The five-year means of $\mathrm{SOC}$ ranged from $1.5 \pm 0.1 \mu \mathrm{gC} \mathrm{m}^{-3}$ at Penghu to $3.8 \pm 0.3 \mu \mathrm{gC} \mathrm{m}^{-3}$ at Taichung. The results showed that the SOC did not exhibit significant urban-rural contrast as did the POC and EC. Instead, the spatial distribution of SOC was characterized by a north-south contrast. A significant cross-station correlation between SOC and total oxidant was observed, which means the spatial distribution of SOC in Taiwan was dominated by the oxidant mixing ratio. Besides, correlation was also found between SOC and particulate nitrate, implying that the precursors of SOA were mainly from local anthropogenic sources. 
In addition to the spatial distribution, the carbonaceous aerosols also exhibited distinct seasonality. In northern Taiwan, the concentrations of all the three carbonaceous components (EC, POC, and SOC) reached their respective minima in the fall season, being consistent with $\mathrm{CO}$ and oxidant. POC and EC increased drastically after the fall season and peaked in spring, whereas the SOC was characterized by a bimodal pattern with the maximal concentration in winter and a second mode in summertime. In southern Taiwan, minimal levels of primary pollutants, i.e. POC, EC, and CO, occurred consistently in summer, and the maxima were observed in winter. In contrast, SOC peaked in summer and declined in wintertime. The discrepancies in the seasonality of carbonaceous aerosols between northern and southern Taiwan were most likely caused by the seasonal meteorological settings that dominated the dispersion of air pollutants. Besides, seasonal cycles of other processes could be also of substantial influences. It was inferred that the Asian outflows of air pollutants could have shifted the seasonal maxima of air pollutants from winter to spring in the northern Taiwan. The increases in the emission of biogenic precursors and the enhancement in the SOA yields were suggested to be responsible for the elevated SOC concentrations in summer.

\section{Supplementary material related to this article is available online at: \\ http://www.atmos-chem-phys.net/10/9563/2010/ acp-10-9563-2010-supplement.pdf.}

Acknowledgements. The authors gratefully acknowledge the financial support from the National Science Council through grants 94-2752-M-001-007-PAE, 95-2752-M-001-006-PAE, 96-2752-M-001-006-PAE and 96-2111-M-001-003-MY3, from the Environmental Protection Administration of Taiwan through grants EPA-92-FA11-03-A141, EPA-93-FA11-03-D037 and EPA-94FA11-03-A165, and from the Academia Sinica thematic projects "Particulate Matter and its Environmental Impact in Taiwan" and "Atmospheric Forcing on Ocean Biogeochemistry (AFOBi)".

Edited by: H. Saathoff

\section{References}

Aiken, A. C., DeCarlo, P. F., Kroll, J. H., Worsnop, D. R., Huffman, J. A., Docherty, K., Ulbrich, I. M., Mohr, C., Kimmel, J. R., Sueper, D., Zhang, Q., Sun, Y., Trimborn, A., Northway, M., Ziemann, P. J., Canagaratna, M. R., Onasch, T. B., Alfarra, M. R., Prevot, A. S. H., Dommen, J., Duplissy, J., Metzger, A., Baltensperger, U., and Jimenez, J. L.: O/C and OM/OC ratios of primary, secondary, and ambient organic aerosols with high resolution time-of-flight aerosol mass spectrometry, Environ. Sci. Technol., 42, 4478-4485, 2008.

Blanchard, C. L., Hidy, G. M., Tanenbaum, S., Edgerton, E., Hartsell, B., and Jansen, J.: Carbon in southeastern U.S. aerosol particles: Empirical estimates of secondary organic aerosol formation, Atmos. Environ., 42, 6710-6720, 2008.
Cabada, J. C., Pandis, S. N., Subramanian, R., Robinson, A. L., Polidori, A., and Turpin, B.: Estimating the secondary organic aerosol contribution to $\mathrm{PM}_{2.5}$ using the EC tracer method, Aerosol Sci. Technol., 38, 140-155, 2004.

Castro, L. M., Pio, C. A., Harrison, R. M., and Smith, D. J. T.: Carbonaceous aerosol in urban and rural European atmospheres: estimation of secondary organic carbon concentrations, Atmos. Environ., 33, 2771-2781, 1999.

Chang, S.-C., Chou, C. C.-K., Chan, C.-C., and Lee, C.-T.: Temporal characteristics from continuous measurements of $\mathrm{PM}_{2.5}$ and speciation at the Taipei Aerosol Supersite from 2002 to 2008, Atmos. Environ., 44, 1088-1096, 2010.

Chen, L. W. A., Doddridge, B. G., Dickerson, R. R., Chow, J. C., Mueller, P. K., Quinn, J., and Butler, W. A.: Seasonal variations in elemental carbon aerosol, carbon monoxide and sulfur dioxide: Implications for sources, Geophys. Res. Lett., 28(9), 17111714, 2001.

Chio, C.-P., Cheng, M.-T., and Wang, C.-F.: Source apportionment to $\mathrm{PM}_{10}$ in different air quality conditions for Taichung urban and coastal areas, Taiwan, Atmos. Environ., 38, 6893-6905, 2004.

Chou, C. C.-K., Lee, C.-T., Yuan, C. S., Hsu, W. C., Hsu, S. C., and Liu, S. C.: Implications of the chemical transformation of Asian outflow aerosols for the long-range transport of inorganic nitrogen species, Atmos. Environ., 42, 7508-7519, 2008.

Chow, J., Watson, J., Lowenthal, D. H., and Merrifield, T.: Comparison of IMPROVE and NIOSH carbon measurements, Aerosol Sci. Technol., 34, 23-34, 2001.

Cocker, D. R., Flagan, R. C., and Seinfeld, J. H.: State-of-the-art chamber facility for studying atmospheric aerosol chemistry, Environ. Sci. Technol., 35, 2594-2601, 2001.

Davidson, C. I., Phalen, R. F., and Solomon, P. A.: Airborne particulate matter and human health: A review, Aerosol Sci. Technol., 39, 737-749, 2005.

Docherty, K. S., Stone, E. A., Ulbrich, I. M., DeCarlo, P. F., Snyder, D. C., Schauer, J. J., Peltier, R. E., Weber, R. J., Murphy, S. M., Seinfeld, J. H., Eatough, D. J., Grover, B. D., and Jimenez, J. L.: Apportionment of primary and secondary organic aerosols in Southern California during the 2005 study of organic aerosols in riverside (SOAR), Environ. Sci. Technol., 42, 7655-7662, 2008.

Donahue, N. M., Robinson, A. L., and Pandis, S. N.: Atmospheric organic particulate matter: from smoke to secondary organic aerosol, Atmos. Environ., 43, 94-106, 2009.

Edney, E. O., Kleindienst, T. E., Jaoui, M., Lewandowski, M., Offenberg, J. H.,Wang,W., and Claeys, M.: Formation of 2-methyl tetrols and 2-methylglyceric acid in secondary organic aerosol from laboratory irradiated isoprene/ $/ \mathrm{NO}_{\mathrm{x}} / \mathrm{SO}_{2} /$ air mixtures and their detection in ambient $\mathrm{PM}_{2.5}$ samples collected in the eastern United States, Atmos. Environ., 39, 5281-5289, 2005.

Forstner, H. J. L., Flagan, R. C., and Seinfeld, J. H.: Molecular speciation of secondary organic aerosol from photooxidation of the higher alkenes: 1-octene and 1-decene, Atmos. Environ., 31, 1953-1964, 1997.

Gelencser, A., May, B., Simpson, D., Sanchez-Ochoa, A., Kasper-Giebl, A., Puxbaum, H., Caseiro, A., Pio, C., and Legrand, M.: Source apportionment of $\mathrm{PM}_{2.5}$ organic aerosol over Europe: primary/secondary, natural/anthropogenic, fossil/biogenic origin, J. Geophys. Res., 112, D23S04, doi:10.1029/2006JD008094, 2007. 
Gray, H. A. and Cass, G. R.: Characteristics of atmospheric organic and elemental carbon particle concentrations in Los Angeles, Environ. Sci. Technol., 20, 580-589, 1986.

Han, S., Kondo, Y., Oshima, N., Takegawa, N., Miyazaki, Y., Hu, M., Lin, P., Deng, Z., Zhao, Y., Sugimoto, N., and Wu, Y.: Temporal variations of elemental carbon in Beijing, J. Geophys. Res., 114, D23202, doi:10.1029/2009JD012027, 2009.

Hallquist, M., Wenger, J. C., Baltensperger, U., Rudich, Y., Simpson, D., Claeys, M., Dommen, J., Donahue, N. M., George, C., Goldstein, A. H., Hamilton, J. F., Herrmann, H., Hoffmann, T., Iinuma, Y., Jang, M., Jenkin, M. E., Jimenez, J. L., Kiendler-Scharr, A., Maenhaut, W., McFiggans, G., Mentel, Th. F., Monod, A., Prévôt, A. S. H., Seinfeld, J. H., Surratt, J. D., Szmigielski, R., and Wildt, J.: The formation, properties and impact of secondary organic aerosol: current and emerging issues, Atmos. Chem. Phys., 9, 5155-5236, doi:10.5194/acp-95155-2009, 2009.

Hoell, J. M., Davis, D. D., Liu, S. C., Newell, R., Akimoto, H., McNeal, R. J., and Bendura, R. J.: The Pacific Exploratory MissionWest Phase B: February-March, 1994, J. Geophys. Res., 102, 28223-28240, 1997.

Hu, Y., Odman, M. T., and Russell, A. G.: Top-down analysis of the elemental carbon emissions inventory in the United States by inverse modeling using Community Multiscale Air Quality model with decoupled direct method (CMAQ-DDM), J. Geophys. Res., 114, D24302, doi:10.1029/2009JD011987, 2009.

Huebert, B. J., Bates, T., Russell, P. B., Shi, G., Kim, Y. J., Kawamura, K., Carmichael, G., and Nakajima, T.: An overview of ACE-Asia: Strategies for quantifying the relationships between Asian aerosols and their climatic impacts, J. Geophys. Res., 108, 8633, doi:10.1029/2003JD003550, 2003.

Iinuma, Y., Boge, O., Gnauk, T., and Herrmann, H.: Aerosol chamber study of the $\alpha$-pinene $/ \mathrm{O}_{3}$ reaction: Influence of particle acidity on aerosol yields and products, Atmos. Environ., 38, 761$773,2004$.

Intergovernmental Panel on Climate Change (IPCC): Climate Change 2007: The Physical Science Basis, Cambridge University Press, UK, 2007.

Jacob, D. J., Crawford, J. H., Kleb, M. M., Connors, V. S., Bendura, R. J., Raper, J. L., Sachse, G. W., Gille, J. C., Emmons, L., and Heald, C. L.: Transport and Chemical Evolution over the Pacific (TRACE-P) aircraft mission: Design, execution, and first results, J. Geophys. Res., 108, 9000, doi:10.1029/2002JD003276, 2003.

Jang, M. and Kamens, R. M.: Newly characterized products and composition of secondary aerosols from reaction of $\alpha$-pinene with ozone, Atmos. Environ., 33, 459-474, 1999.

Jenkin, M. E.: Modelling the formation and composition of secondary organic aerosol from $\alpha$ - and $\beta$-pinene ozonolysis using MCM v3, Atmos. Chem. Phys., 4, 1741-1757, doi:10.5194/acp4-1741-2004, 2004.

Johnson, D., Utembe, S. R., and Jenkin, M. E.: Simulating the detailed chemical composition of secondary organic aerosol formed on a regional scale during the TORCH 2003 campaign in the southern UK, Atmos. Chem. Phys., 6, 419-431, doi:10.5194/acp-6-419-2006, 2006.

Kanakidou, M., Seinfeld, J. H., Pandis, S. N., Barnes, I., Dentener, F. J., Facchini, M. C., Van Dingenen, R., Ervens, B., Nenes, A., Nielsen, C. J., Swietlicki, E., Putaud, J. P., Balkanski, Y., Fuzzi, S., Horth, J., Moortgat, G. K., Winterhalter, R., Myhre, C. E.
L., Tsigaridis, K., Vignati, E., Stephanou, E. G., and Wilson, J.: Organic aerosol and global climate modelling: a review, Atmos. Chem. Phys., 5, 1053-1123, doi:10.5194/acp-5-1053-2005, 2005.

Klotz, B., Sorensen, S., Barnes, I., Becker, K. H., Etzkorn, T., Volkamer, R., Platt, U., Wirtz, K., and Martin-Reviejo, M.: Atmospheric oxidation of toluene in a large-volume outdoor photoreactor: in situ determination of ring-retaining product yields, J. Phys. Chem., 102, 10289-10299, 1998.

Kondo, Y., Komazaki, Y., Miyazaki, Y., Moteki, N., Takegawa, N., Kodama, D., Deguchi, S., Nogami, M., Fukuda, M., Miyakawa, T., Morino, Y., Koike, M., Sakurai, H., and Ehara, K., Temporal variations of elemental carbon in Tokyo, J. Geophys. Res., 111, D12205, doi:10.1029/2005JD006257, 2006.

Li, Q., Hu, D., Leungsakul, S., and Kamens, R. M.: Large outdoor chamber experiments and computer simulations: (I) Secondary organic aerosol formation from the oxidation of a mixture of limonene and $\alpha$-pinene, Atmos. Environ., 41(40), 9341-9352, 2007.

Lin, C.-Y., Liu, S. C., Chou, C. C.-K., Huang, S.-J., Liu, C.-M., Kuo, C.-H., and Young, C.-Y.: Long-range transport of aerosols and their impact on the air quality of Taiwan, Atmos. Environ., 39, 6066-6076, 2005.

Lin, P., Hu, M., Deng, Z., Slanina, J., Han, S., Kondo, Y., Takegawa, N., Miyazaki, Y., Zhao, Y., and Sugimoto, N.: Seasonal and diurnal variations of organic carbon in $\mathrm{PM}_{2.5}$ in Beijing and the estimation of secondary organic carbon, J. Geophys. Res., 114, DooG11, doi:10.1029/2008JD010902, 2009.

Lippmann, M.: Health effects of airborne particulate matter, N. Engl. J. Med., 357, 2395-2397, 2007.

Liu, H., Jacob, D. J., Bey, I., Yantosca, R. M., Duncan, B. N., and Sachse, G. W.: Transport pathways for Asian pollution outflow over the Pacific: Interannual and seasonal variations, J. Geophys. Res., 108, 8786, doi:10.1029/2002JD003102, 2003.

McMurry, P., Shepherd, M., and Vickery, J.: Particulate matter science for policy makers: A NARSTO assessment, Cambridge University Press, New York, 2004.

Miyazaki, Y., Kondo, Y., Takegawa, N., Komazaki, Y., Fukuda, M., Kawamura, K., Mochida, M., Okuzawa, K., and Weber, R. J.: Time-resolved measurements of water-soluble organic carbon in Tokyo, J. Geophys. Res., 111, D23206, doi:10.1029/2006JD007125, 2006.

Ng, N. L., Kroll, J. H., Keywood, M. D., Bahreini, R., Varutbangkul, V., Flagan, R. C., Seinfeld, J. H., Lee, A. and Goldstein, A. H.: Contributions of first- versus second-generation products to secondary organic aerosols formed in the oxidation of biogenic hydrocarbons, Environ. Sci. Technol., 40, 2283-2297, 2006.

Odum, J. R., Hoffmann, T., Bowman, F., Collins, D., Flagan, R. C., and Seinfeld, J. H.: Gas/particle partitioning and secondary organic aerosol yields, Environ. Sci. Technol., 30, 2580-2585, 1996.

Park, S. S., Bae, M. S., Schauer, J. J., Ryu, S. Y., Kim, Y. J., Cho, S. Y., and Kim, S. J.: Evaluation of the TMO and TOT methods for OC and EC measurements and their characteristics in $\mathrm{PM}_{2.5}$ at an urban site of Korea during ACE-Asia, Atmos. Environ., 39, 5101-5112, 2005.

Pathak, R. K., Presto, A. A., Lane, T. E., Stanier, C. O., Donahue, N. M., and Pandis, S. N.: Ozonolysis of a-pinene: parameterization of secondary organic aerosol mass fraction, Atmos. Chem. Phys., 
7, 3811-3821, doi:10.5194/acp-7-3811-2007, 2007.

Polidori, A., Turpin, B. J., Lim, H.-J., Cabada, J. C., Subramanian, R., Pandis, S. N., and Robinson, A. L.: Local and regional secondary organic aerosol: Insights from a year of semi-continuous carbon measurements at Pittsburgh, Aerosol Sci. Technol., 40, 861-872, 2006.

Pope III, C. A. and Dockery, D. W.: Health effects of fine particulate air pollution: Lines that connect, J. Air Waste Manage., 56, 709742, 2006.

Presto, A. A. and Donahue, N. M.: Investigation of $\alpha$-pinene + ozone secondary organic aerosol formation at low total aerosol mass, Environ. Sci. Technol., 40, 3536-3543, 2006.

Russell, M. and Allen, D. T.: Predicting secondary organic aerosol formation rates in southeast Texas, J. Geophys. Res., 110, D07S17, doi:10.1029/2004JD004722, 2005.

Russell, M., Allen, D. T., Collins, D. R., and Fraser, M. P.: Daily, seasonal, and spatial trends in $\mathrm{PM}_{2.5}$ mass and composition in southeast Texas, Aerosol Sci. Technol. 38, 14-26, 2004.

Saathoff, H., Naumann, K.-H., Möhler, O., Jonsson, Å. M., Hallquist, M., Kiendler-Scharr, A., Mentel, Th. F., Tillmann, R., and Schurath, U.: Temperature dependence of yields of secondary organic aerosols from the ozonolysis of a-pinene and limonene, Atmos. Chem. Phys., 9, 1551-1577, doi:10.5194/acp-9-1551-2009, 2009.

Sato, K., Hatakeyama, S., and Imamura, T.: Secondary organic aerosol formation during the photooxidation of toluene: $\mathrm{NO}_{\mathrm{x}}$ dependence of chemical composition, J. Phys. Chem. A, 111, 9796-9808, 2007.

Schauer, J. J., Fraser, M. P., Cass, G. R., and Simoneit, B. R. T.: Source reconciliation of atmospheric gas-phase and particlephase pollutants during a severe photochemical smog episode, Environ. Sci. Technol., 36, 3806-3814, 2002.

Schauer, J. J., Rogge, W. F., Hildemann, L. M., Mazurek, M. A., and Cass, G. R.: Source apportionment of airborne particulate matter using organic compounds as tracers, Atmos. Environ., 30, 3837-3855, 1996.

Seinfeld, J. H., Erdakos, G. B., Asher, W. E., and Pankow, J. F.: Modeling the formation of secondary organic aerosols: 2 . The predicted effects of relative humidity on aerosol formation in the $\alpha$-pinene-, $\beta$-pinene-, sabinene-, ${ }^{3}$-carene, and cyclohexeneozone systems, Environ. Sci. Technol., 35, 1806-1817, 2001.
Simpson, D., Yttri, K., Klimont, Z., Kupiainen, K., Caseiro, A., Gelencs'er, A., Pio, C., and Legrand, M.: Modeling carbonaceous aerosol over Europe, Analysis of the CARBOSOL and EMEP EC/OC campaigns, J. Geophys. Res., 112, D23S14, doi:10.1029/2006JD008158, 2007.

Strader, R., Lurmann, F., and Pandis, S. N.: Evaluation of secondary organic aerosol formation in winter, Atmos. Environ., 33, 48494863, 1999.

Szidat, S., Jenk, T. M., Synal, H.-A., Kalberer, M., Wacker, L., Hajdas, I., Kasper-Giebl, A., and Baltensperger, U.: Contributions of fossil fuel, biomass burning, and biogenic emissions to carbonaceous aerosols in Zurich as traced by ${ }^{14} \mathrm{C}$, J. Geophys. Res., 111, D07206, doi:10.1029/2005JD006590, 2006.

Taiwan EPA: Taiwan emission data statistics, Ver.7.0, 2010.

Takegawa, N., Miyakawa, T., Kondo, Y., Jimenez, J. L., Zhang, Q., Worsnop, D. R., and Fukuda, M.: Seasonal and diurnal variations of submicron organic aerosols in Tokyo observed using the Aerodyne aerosol mass spectrometer (AMS), J. Geophys. Res., 111, D11206, doi:10.1029/2005JD006515, 2006.

Turpin, B. J. and Huntzicker, J. J.: Identification of secondary organic aerosol episodes and quantitation of primary and secondary organic aerosol concentrations during SCAQS, Atmos. Environ., 29, 3527-3544, 1995.

Turpin, B. J. and Lim, H. J.: Species contributions to $\mathrm{PM}_{2.5}$ mass concentrations: Revisiting common assumptions for estimating organic mass, Aerosol Sci. Technol., 35, 602-610, 2001.

Yu, X.-Y., Cary, R. A., and Laulainen, N. S.: Primary and secondary organic carbon downwind of Mexico City, Atmos. Chem. Phys., 9, 6793-6814, doi:10.5194/acp-9-6793-2009, 2009.

Yuan, Z. B., Yu, J. Z., Lau, A. K. H., Louie, P. K. K., and Fung, J. C. H.: Application of positive matrix factorization in estimating aerosol secondary organic carbon in Hong Kong and its relationship with secondary sulfate, Atmos. Chem. Phys., 6, 25-34, doi:10.5194/acp-6-25-2006, 2006.

Zhang, Q., Streets, D. G., Carmichael, G. R., He, K. B., Huo, H., Kannari, A., Klimont, Z., Park, I. S., Reddy, S., Fu, J. S., Chen, D., Duan, L., Lei, Y., Wang, L. T., and Yao, Z. L.: Asian emissions in 2006 for the NASA INTEX-B mission, Atmos. Chem. Phys., 9, 5131-5153, doi:10.5194/acp-9-5131-2009, 2009. 